\title{
جوائز الإيداعات المصرفية
}

\author{
shel \\ أ.د / يوسف حسن الشراح \\ أستاذ مساعد بكليت الشريعتَوالدراسات \\ الإسلاميتَجامعت الكويت
}




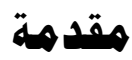

الحمــ لله رب العـالمين ، والـصلاة والسلام على أشـرف الأنبيـاء والمرسـلين و والمبعوث رحمة للعالمين ، وبعد :

فلقد بيّن الله تعالى معالم الدين لمّا جعل الإسـلام خـاتم أديان المرسلين ، فكان

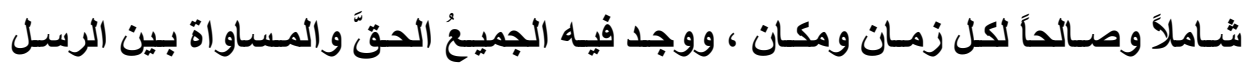

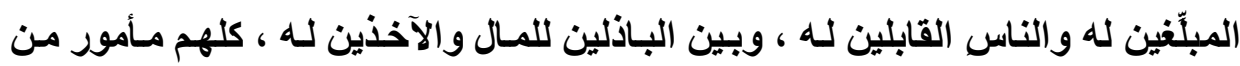

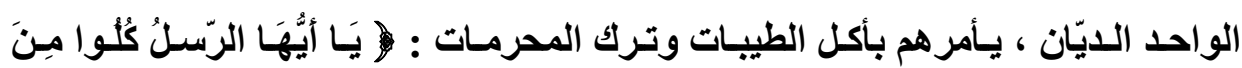

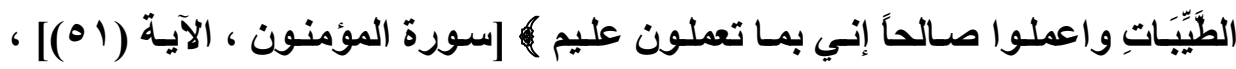

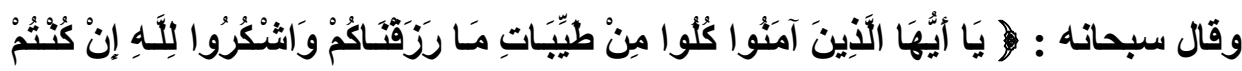

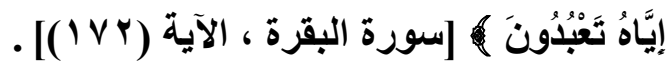
وقد نمس الاهتمـام بالقضايا الاقتصادية الإسـلامية المستجدة عند كثير مـن

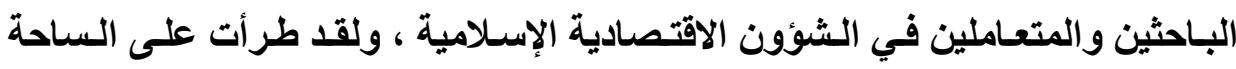
الاقتصادية عدة قضايا مهمة بدأت تشكل اهتمامسا مباشراً في عمل المؤسسات المالية الإسلامية ، ومنها الجوائز و الهايا التي تقدمها الجهات الكثيرة .

و الملاحظ على السوق والواقع في هذه القضية أن الغش والخداع صـار ديدناً شائعاً ، يُستففل بـه الطامعون لتحصيل دراهم كثيرة بأسرع وأسهـل الطرق ، حتى إذا مرّت سنون طويلة من المعاناة صار لاى بعض الناس مناعة ضد هذه الخدع التسويقية

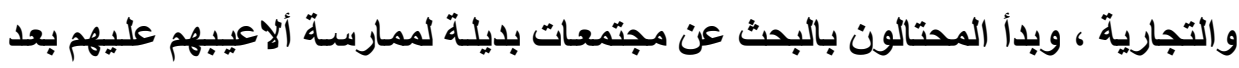

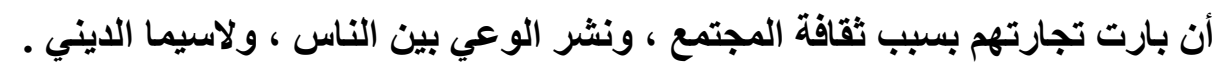


ولذا جـاعت هذه الدراسـة المتواضعة لبيـان جانب من تلك اللدعايات والجوائز

والهدايا المعطاة على الإيداعات المصرفية ، تناولته في مبحثين على النحو الآتي :

المبحث الأول : مفهوم الجوائز والمقامرات والإيداعات المصرفية ـ وفيه مطلبان:

المطلب الأول : معنى الجوائز والمقامرات لغة واصطلاحاً.

المطلب الثاني : أنواع الإيداعات المصرفية وحكمها .

المبحث الثاني : حكم الإيداعات المصرفية ـ وفيه أربعة مطالب :

المطلب الأول : جوائز الإيداعات المصرفية وصورها .

المطلب الثاني : حكم الجوائز على الحسابات الجارية .

المطلب الثالث : حكم الجوائز على حسابات التوفير الاسـتثماري والودائـع

الاستثمارية .

المطلب الرابع : حكم السحوبات على أنواع الحسابات المصرفية .

ثم تأتي الخاتمة مبيناً فيها أهم النتائج التي توصلت إليها ، مـع بعض التوصيات ،

والله أسأل التوفيق والسداد ، والهـي والرشاد ، والحمد لله رب العالمين . 


\section{المبحث الأول}

هفهوم الجوائز والمقاهرات والإيداعات المصرفية

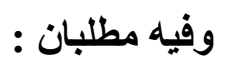

المطلب الأول : مغنى الجوائز و المقامر ات لغة واصطلاحاً.

المطلب الثاني : أنواع الإيداعات المصرفية وحكمها .

\section{المطلب الأول}

هعنى الجوائز والمقاهرات لغة واصطلاحاً

لعل من المناسب في سياق البحث عن حكم الجوائز على الإيداعات المصرفية أن

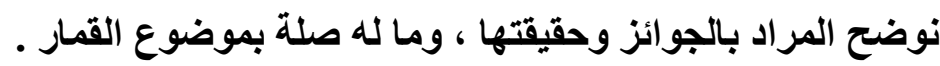

\section{الفرع الأول}

هعنى الجوائز لغة واصطلاحاً

أولاً : الجوائز لغة :

الجوائز جمع جائزة ، وأصلها من أجـازه مـاءً يجوز بـه المسافر الطريق من

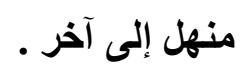

مجل 
وتطلق الجائزة أيضاً على الشربة الواحدة من المساء ، ثم كثر استعمالها على

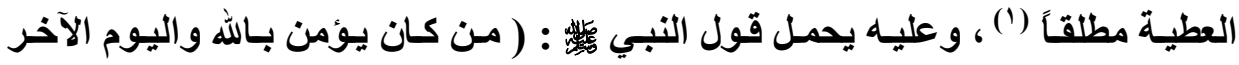

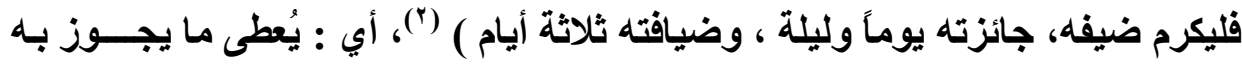

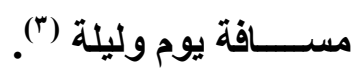
ثانياً : الجموائز اصطلاحماً :

لم ينص الفقهاء صراحة على تعريف محدد للجوائز ، غير الذي ذكر في بـاب الضيافة ، والذي سبق ذكر الحديث فيه ، وفصلوا القول فيها وفي أحكامها (؛). وهي ما يعطى للمسافر ليتبلغ به في سفره ، وذكرت الجائزة في مباحث الضيافة

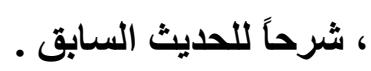

فالضيافة في صورتها جـائزة للضيف وللمسافر ، وفي مجلهها عطية وتبرع

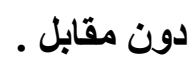

ولذا فقد عرف ابن قدامة الضيافة في هذا الباب فقال : والضيافة معناهـا معنى

صدقة التطوع ، على المسلم والكافر (॰)

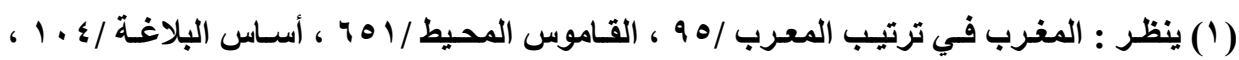

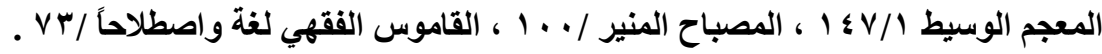

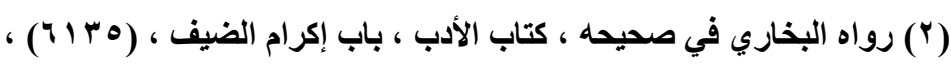
ورواه مسلم في صحيحه ، كتاب اللقطة ، باب الضيافة ، (^^ ؛) .

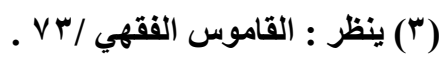

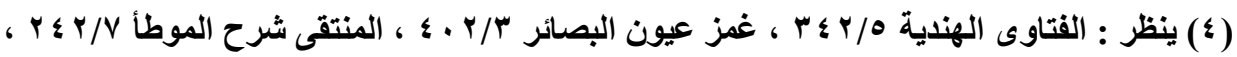

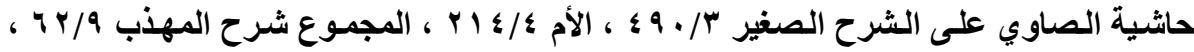

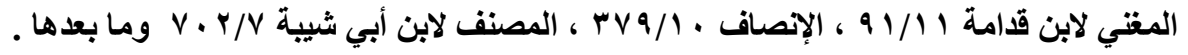


ومـن خـلال مـا سبق يتبين أن المعنى الاصطلاحي للجـائزة ربمـا لا يخرج عن

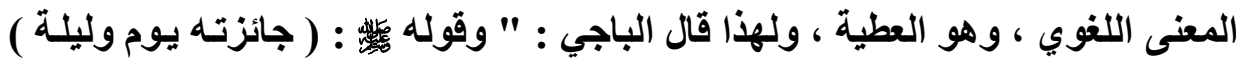

يحتمل أن يريد - والله أعلم - منحته وعطيته ؛ لأن الجائزة : العطية " (')

\section{الفرع الثانتي \\ همنى الإقاهرة لغةًّ واصطلاحًا}

أولاًا : الاقامهرة لغة

المقامرة مفاعلة من قامره مقامرة وقمـارً ؛ أي لاعبـه القمسار ، ويراد بها في

اللغة المراهنة ؛ فيقال : راهنه فظلبه .

وأصل المقـامرة في كـلام العرب المغابنـة ، يقـال : قـامره قمـاراً ومقـامرة : إذا

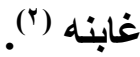

فالقمار في اللغة هو كل لعب فيه مراهنة .

ثانياً : الاقاهمرة اصطلاهاً :

المقامرة في الاصطلاح هي : كل لعب يشترط فيه غالباً من المتغـالبين شيئًا من

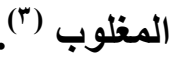

$$
\text { (1) بنظر : المنتقى (1) }
$$

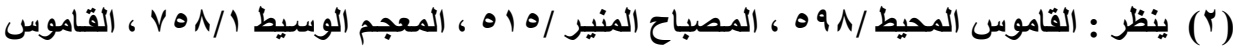

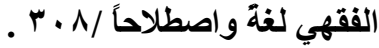

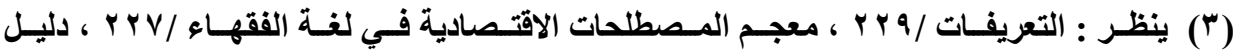

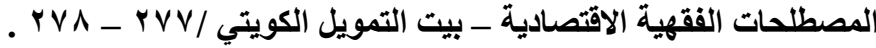


ويطلق كثير من الفقهاء على القمسار اسم الميسر ، وإن كسان لفظ القمار في

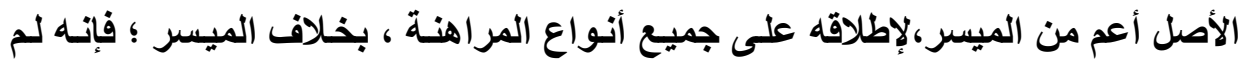
يكن يطلق إلا على المقامرة بالأقداح لاقتسام الجزور بطريقة خاصـة على عادة أهل

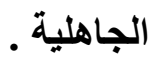

و المقامرة هي مراهنة على أمر محتمل الوقوع ، وهي غرر محض في حصول

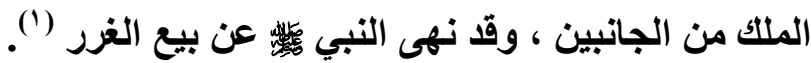
ولذا كانت المقامرة غير مشروعة باتفاق الفقهاء (")

\section{المطاب الثاني \\ الإيداعات المصرفية}

مـع تطور وتقدم العمل المصرفي ظهرت صسور ونمساذج استثمارية مصرفية

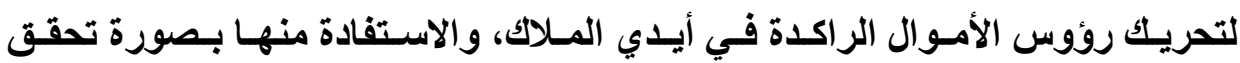
المصلحة للجميع ، مع تحفظنا على الكيفية التي تتنهجها المصارف التقليدية في طريقة استثماراتها لهذه الأموال المجمعة ، ولقد تعددت صور هذه الإيداعات التي يودعها الناس لاى المصارف المختلفة وأغراضها ـ وفي هذا المطلب سوف نتطرق لمعنى هذه

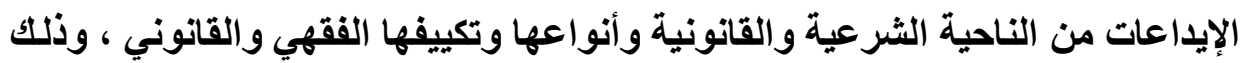

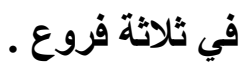

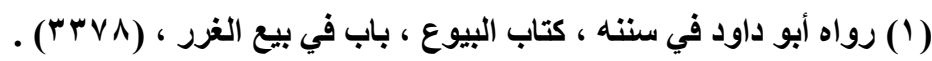

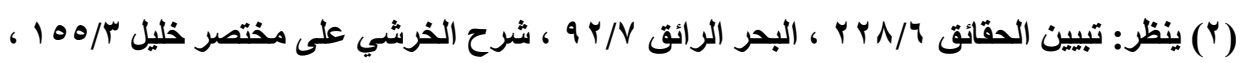

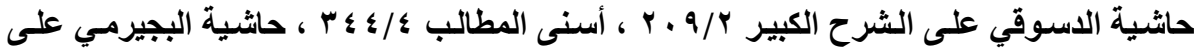

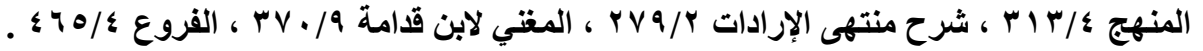




\section{الفرع الأول

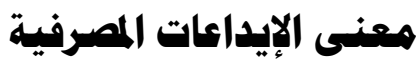

الودائع المصرفية النقدية في العرف المصرفي نوعان : ودائع عينية حقيقية ؛ كايداع شخص أشياء لاى المصرف ، حيث توضع في خزائن حديدية بالأجرة ، وهي

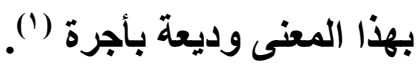

و والوديعة من حيث المغنى اللغوي مشتقة من ودعته أدعه ودعـا ؛ أي تركته ،

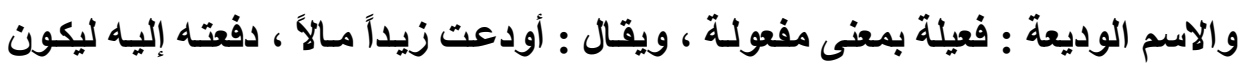

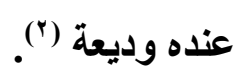

$$
\text { فالوديعة في اللغة : هي الترك . }
$$

وأما في الاصطلاح فهي : أمانة تركت عند الغير للحفظ قصداً (").

وهي بهذا المغنى توكيل من المالك أو نائبه للآخر لحفظ مال واختصاص (') و النوع الثاني من الودائع النقدية المصرفية هي الودائع النقدية التي تعطى للبنتك

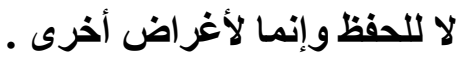

(1) الوديعة بأجر جائزة عند الحنفية ، وهي مضمونة عندهم ؛ كما قال الزيلعي في تبيين الحقائق

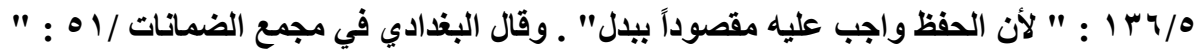

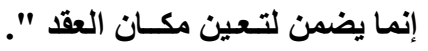

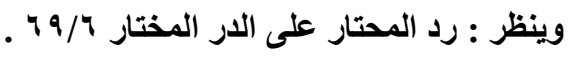

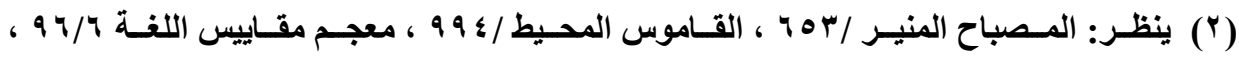

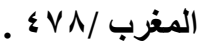

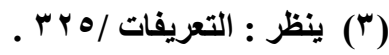

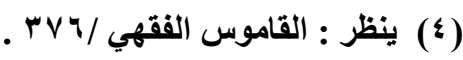


ولقد اكتسبت المؤسسات الاقتصادية صفة المصرف أو البنك من خلال تقبلها

لتبلك الودائع النقدية .

يقول د. محي الدين إسماعيل : " أما المنشآت التي تباشر نشاطاً اقتصادياً : قد

يكون العنصر الأساسي فيه هو تلقي الودائع من الغير ، فتسمى بنوكاً تجارية " ( ).

والودائع المصرفية هي أحد أساليب الخدمات المصرفية التي يقدمها المصرف ،

سواء منها التقليدي أم الإسـلامي على حد سواء ، والاختلاف إنمـا يكون في التكييف

والشروط فقط .

والودائع المصرفية في عرف علماء القانون التجاري عبارة عن : النقود التي

يعهد بها الأفراد أو الهيئات إلى البنك ، على أن يتعهد الأخير بردها ، أو برد مبلغ مساو إليهم لاى الطلب ، أو بالشروط المتقق عليها (†).

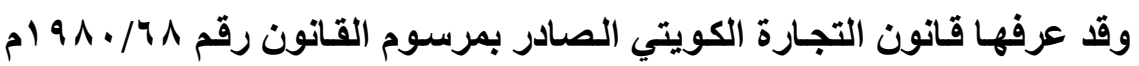

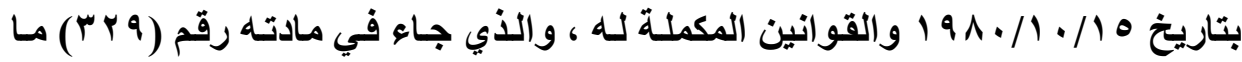
نصها : "وديعة النقود عقد يخول البنك ملكية النقود المودعة والتصرف فيها بما يتفق ونـشاطه المهنـي مـع التزامـه بـرد مثلهـا للمـودع ، ويكـون الـرد بـذات نـوع العملـة

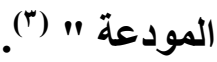

وعلى هذا فالودائع المصرفية هي عبارة عن قبول المصرف الأموال من قبل

الأفراد والمؤسسات مع الاختلاف في تكييفها الشرعي والقانوني .

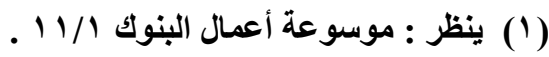

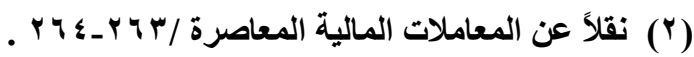

(r) ينظر : قانون التجارة الكويتي /111 .

مجلتّ البحوث القانونيت والإقتصاديت . . 
وإذا نظرنـا إلى هذا المعنى الاصطلاحي نجد أن المبالغ المودعة لـى البنـوك التقليديـة ـ وحتى الإسـلامية منهـا ـ ليست ودائـع بـالمعنى الشرعي الدقيق ، ولا على الشى المعنى القاتوني أيضاً (') وقد جـاء في المـادة (• VY) مـن القـانون المـدني الكويتي أن : " الإيداع عقد يلتزم الوديع بمقتضاه أن يتسلم من المودع شيئًا لحفظه ، وأن يرده عيناً " ("). وهي تسمية منتقدة كما سنرى عند كلامنا على التكييف الفقهي للودائع ، وربمـا صدقت هذه التسمية على النوع الأول من أنواع الودائع المصرفية .

\section{الفنرع الثانتي \\ أنواع الإيداعات المصرفية}

تعد الودائـع المـصرفية مـن أهـم مـصادر الأمسوال غير الذاتيـة في المؤسسسات الماليـة المـصرفية سـواء منهــا الإسـلامية وغيرهــا ، إلا أن مسسمياتها ومــامينها وتكييفاتها تكون مختلفة (")

(1) ينظر : بحـوث في المعساملات والأسـاليب المصرفية الإسـلامية / . . r ، الشامل في معساملات

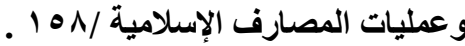

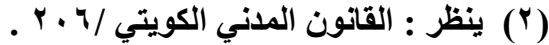

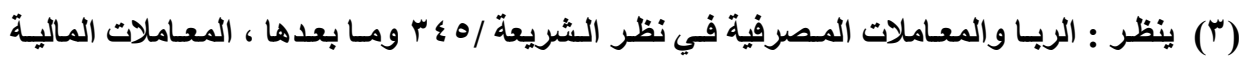

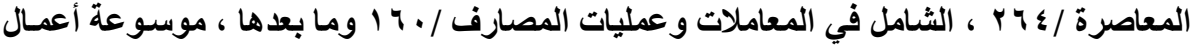

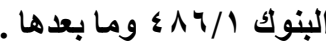
مجلتّ البحوث القانونيت والإقتصاديت 1. 
أ ـ الودائع الجاربة " تحت الطلب " : وهي : المبالغ التي يودعها أصحابها في

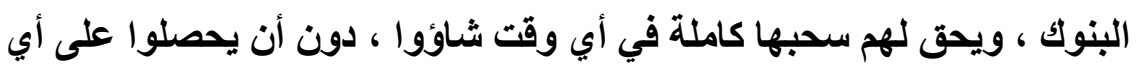

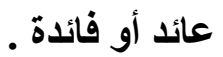

فيجوز لأصحابها سـحبها منى شـاؤوا واستردادها في أي وقت أرادوا ، دون

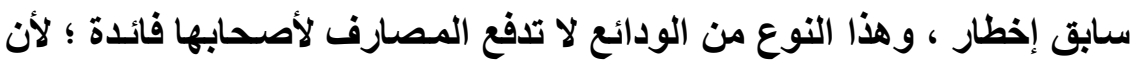

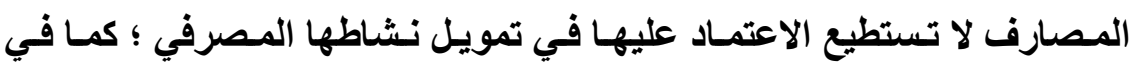
الودائع لأجل ؛ ولما تقتضيه الضرورة من احتفاظ المصرف في خزانته بأموال

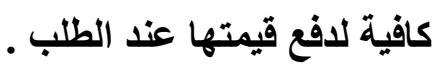
وهذا النوع هو ما يسىى بالحساب الجاري ، وأحيانًا تأخذ المصارف عمولة في حال تكرار السحب منها مرات ومرات ، مقابل فتح الحساب ، ذلكك أن العميل يتفق مع البنك على أن يخصص له حساباً لعملياته معه يسمى الحساب الجاري .

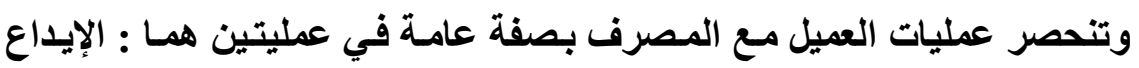

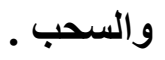

بـ ودائع ثابتـة (لأجل ) : أي محددة لأجل معين ، فلا تسترد قبل انتهاء الأجل

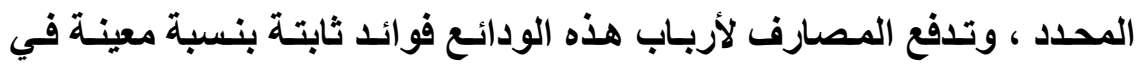

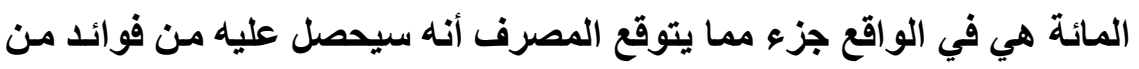

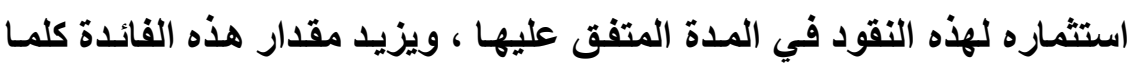

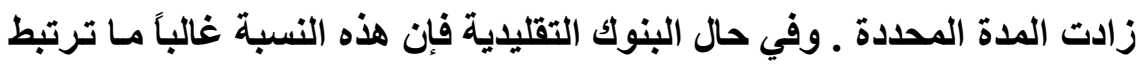

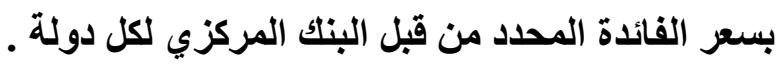


فالودائع الثابتة "لأجل" : هي المبالغ التي يودعها أصحابها في البنك بناء على

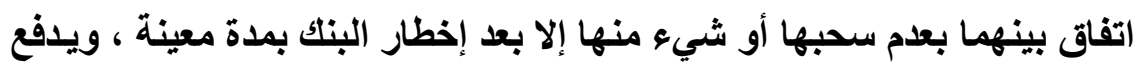

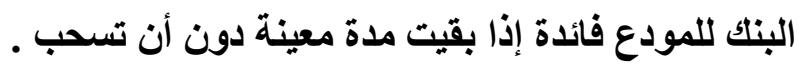
ج- ودائع الخار ( توفير ) : وهي المبالغ التي يودعها أصحابها في البنك، ويحق

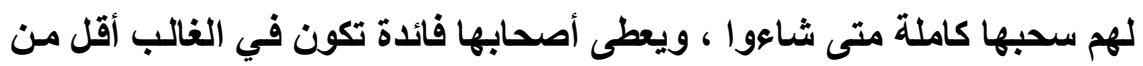

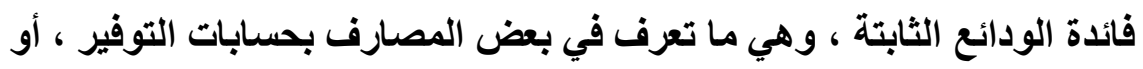

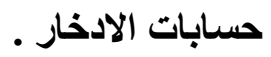

\title{
الفرع الثالث \\ التكييف القانوني للإيداعات الصرفية وحكمها الشرعي
}

\author{
أولاً : المساب الجاري ( الودائع الجارية ) : \\ أ - التكييف القانوني (1) \\ فكرة الحساب الجاري ("): - ت
}

عندما تتكرر وتتصل علاقة الأعمال بين شخصين ، بحيث يكون كل منهما مديناً

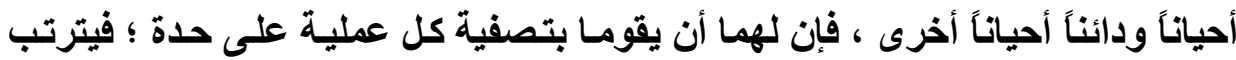

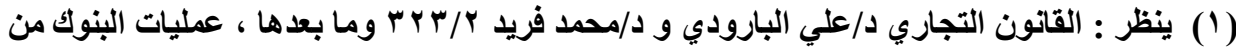

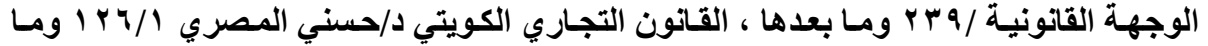

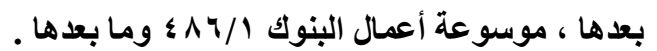

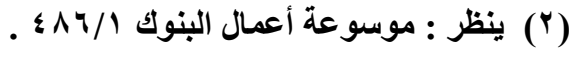


على ذلك أن تعقب كل عملية تقوم بينهما عملية أخرى هي عملية الوفاء أو التسوية ، فتخرج النقود مرة من أحدها إلى الآخر ثم تعود مرة ثانية إلى الأول ، و هكذا ، و عندئذ قد يجد هذان الطرفان أنه من الأوفق ألا يقومـا بتصفية كل عملية بطريقة مستقلة ،

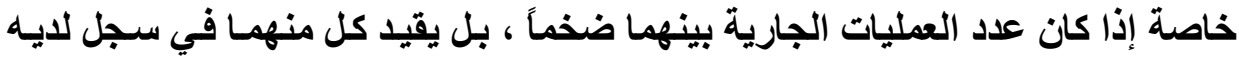
مقدار ما أصبح دائناً به من جراء هذه العمليات ، ثم يجتمع الطرفان بعد وقت معين ليقوما بتصفية هذه العمليات دفعة واحدة فيوفران بذلك الوقت والمجهود ، ومن هنا نثأت فكرة الحساب الجاري ، ولكن السساب الجاري ليس مجرد صورة مسجلة من هذه العمليات المتبادلة بحيث يقتصر أثرها على مجرد إنعاش ذاكرة طرفي الحساب ساعة التصفية ، بل هو شكل قانوني حسابي خاص بعيد الأثر في علاقات طرفية ؛ ذلكت

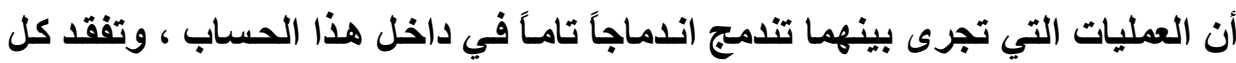
عملية ذاتيتها واستقلالها بمجرد قيدها فيه ، فلا يعد أحد الطرفين ـ طالمـا طل هذا لها الحساب بينهما مفتوحاً ـ دائناً للآخر في عملية أو أخرى ، و إنما يعد كل منهما في حالة

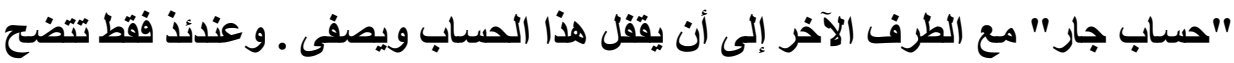

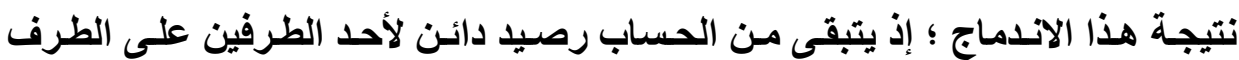

يقول د/محيـي الـدين إسـماعيل : " كـان بعض الكتاب ينظرون إلى الحساب الجاري بين تاجرين على أنه قرض ووديعة ناقصة ، بينمـا يراه آخرون قرضاً متبادلاً

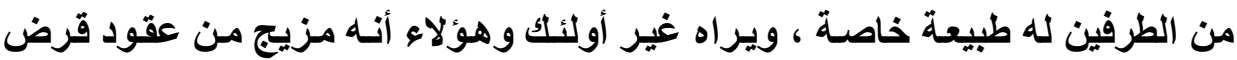
ووديعة وحوالة ، ثم حلت محل هذه الأفكار ، النظريـة التقليدية التي اتجها إليها الفقهـ و القضاء والتي يعتبر التجايد وعدم التجزئة من أهم معالمها ، ويفضلها أصبح ينظر إلى الحساب الجاري على أنه طريقة لتسوية الديون في الحساب وليس مجرد تبادل 
لأداءات متميزة ؛ بحيث إنه لا يكاد الأداء يوجد حتى يجد الحساب الجاري المعد من قبل ليبتلعه . ولم يعد من الـلازم أن يتأخر التجديد حتى يقفل الحساب ، وإنمـا يظهر رصيد فوري للحسـاب يـتم معـه الوفـاء بالـدين ، بمعنى أنسه عندما يقيد ديـن في الحساب الجاري يظهر نتيجة له رصيد جديد للحساب وهكذا " ('). وتتضح طبيعة الحساب الجاري إذا نظرنا إلى تعريفه في قانون التجارة الكويتي، فجاء في المادة (r^^) : " الحساب الجاري عقد يتفق بمقتضاه شخصان على أن يقيلا في حساب عن طريق مدفوعات متبادلة ومتاخلة الديون الناشئة عن العمليات التي تنت بينهمـا ؛ من تسليم نقود ، أو أموال ، أو أوراق تجاريـة قابلـة للتمليك وغيرهـا ،. وأن يستعيضا عن تسوية هذه الديون كل دفعة على حدة بتسوية نهائية ، ينتج عنها رصيد

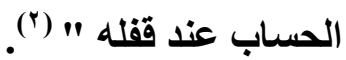

ومن ذلك يتضح أن التكييف الغالب للحساب الجـاري هو القرض ، وعليهه فِان العميل صاحب الحساب يعتبر مقرضاً للبنك ، والبنك مقترضـاً ، علمـاً بأن البنك ضـامن لأصل المال ، وهو ملزم بإعادته إلى صاحبه متى ما طلبه ، وهذا هو حقيقة القرض .

\section{ب- الهكم النقهي (")}

يتضح مما سبق أن طبيعة العلاقة بين الطرفين هو الإقراض والاقتر اض ؛ وعليه فِإن مبدأ القرض والاقتر اض في الشريعة الإسـلامية جـائز غير ممنوع بشرط عدم 
الزيادة على القرض ؛ وعلى ذلك فالحساب الجـاري أو الودائع تحت الطلب جـائزة من حيث الجملة.

يقول د/عمر المترك معللاً الجواز : " حيث إن رب المـال لا يتقاضسى فائدة ، وأمسا بالنسبة لأخذ المصرف عمولة على الحساب الجاري مقابل خدماتـه : فجائز أيضاً ؛ لأن هذا ليس من بـاب القرض الذي جر نفعاً لأن النفع للمقترض أو المودع عنده وهو المصرف ؛ كما أن المودع ينتفع بالخدمات التي يقدمها له المصرف بدون مقابل ؛ فمثلاً يتمكن من أن يطلب من المصرف دفتر شيكات ويستخدمه في معاملاته المالية مما يوفر وقته في عد النقود ومراجعتها عند دفع مبالغ كثيرة ، كمـا أن الحساب الجـاري للى المصارف يعتبر أيسر وسيلة لعمل حسابات نظامية دقيقة عن أي نوع من النشاط يقوم بـه العميل ؛ فمـثلاً إذا كـان العميل تـاجراً أو طبيبـاً جعل جميع إيراداتـه اليوميـة لـدى المـصرف كمـا يجعل مشترياته ومسحوباته تتم عن طريـق شيكات مسحوبة عليهه ، وبذلك فإن زيادة رصيده آخر السنة عن أول السنة يمثل أرباح العيادة عن هذه السنة . كما يستفيد العميل الذي له حساب جار في إمكان إثبات مدفوعاته طالمـا أنها تتم عن طريق الشيكات ، وبالجملة فإن كلاً من الطرفين مستفيد بلا ضرر على الآخر ، ولا

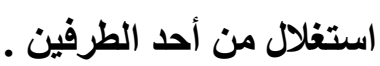

إلا أنه يلاحظ أن إيداع الأموال في المصارف الريويـة يساعد هذه المصارف على استغلالها بالربا ، وهذا فيه أكبر عون على الإثم والعدوان ، والتعاون على الإثم أمر محظور بنص القرآن يجب التنبه إليه "(').

(1 ) ينظر : الربا والمعاملات المصرفية /9 ؛ ؟ . 


\section{ثانياً : ودائع ثابتة لأجل والادخار ( التوفير ) :}

\section{أ - التكييف القانوني (')}

الودائع الثابتة لأجل والادخار لا تختلف من حيث التكييف القانوني في المصارف التقليدية عن الحسابات الجارية ، ولكن في الاشتراطات ، والفو ائد ، والقيود على كلا

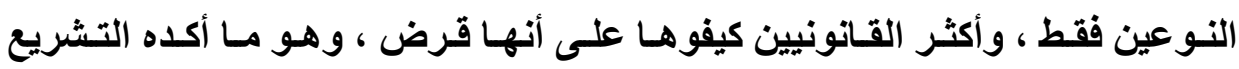
الكويتي؛ ولذا جاء في القانون العدني الكويتي في المادة (VTr) ما نصها : " إذا كانت الوديعة مبلغاً من النقود أو أي شيء آخر مما يهلك بالاستعمال ، وكان الوديع مأذوناً له اله في استعماله ، اعتبر العقد قرضاً " ("). فحقيقة الودائع المصرفية بأنواعها في القانون أنها قروض ، ويحتسب البنك فو ائد على هذه الودائع النقية من جملتها وحسابات التوفير ، وقد ذكر د/محيي الدين إسماعيل مبادئ هذا النوع من الإيداعات فقال : تحتسب فوائد التوفير على أقل رصيد موجود أثناء الشهر ، وتحسب باعتبار السنة ه هب يومـاً وتضاف الفوائد في بطاقة العميل لاى البنك قبل نهاية السنة المالية بشهر ، وعلى العميل أن يتقدم بالدفتر خلال الثهر الأخير من السنة المالية بصرف الفوائد نقداً ، أو لقيدها في الدفتر الموجود لايه ليحصل على فو ائد مركبة ، ولا تحتسب فو ائد على كسور الجنيه ـوفي حال وفاة العميل يستمر احتساب الفوائد حتى تاريخ تصفية التركة (").

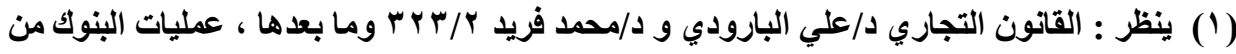

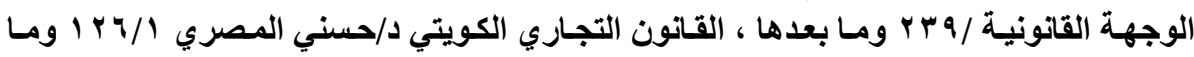

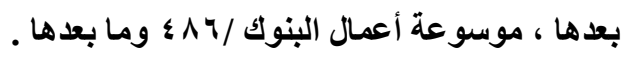

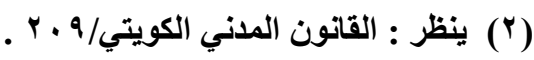

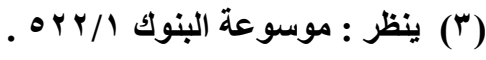




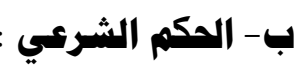

إن المبالغ المودعة في البنوك العادية ليست ودائع بـالمعنى الدقيق ، والتسمية الحالية منتقدة شرعاً وقانوناً حتى سموها ( الوديعة الناقصة )؛لأنها لا تبقي على ملتك صاحبها ، ولا يمنع من هي بيده من التصرف بها ، في حين أن دور المودع لايـه هو الحفظ ، ويمتتع عليه التعدي أو التقصير تحت طائلة التضمين ، علمـاً بـأن القانون قد فـ

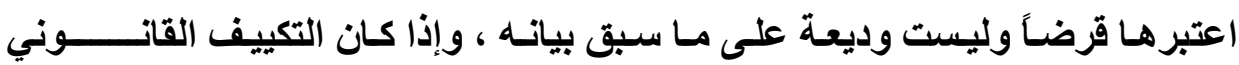
للودائع هو القـرض ؛ فإنه في حد ذاتـه جـائز إذا كـان خالياً من الربـا كمـا في الودائع الجارية ـ لكن الودائسع الاستثمارية والادخاريـة لا تخلو من الربـا ؛ لأن البنـك التقليدي يأخذ الودائع بفائدة محددة سلفاً ، فالبنك يتقاضى عنها فائدة ، فإنها بـلا شك ربـا ؛ لأن حقيقتها إقراض إلى أجل بفائدة فقيها ربا فضل ونسيئة ؛ فأما ربا الفضل فالزيـادة التي يدفعها المصرف زيادة على ما أخذه بناء على الثرط المتفق عليه مع المصرف ، وأمـا ربـا النسيئة ؛ فلتأجيل مـا يدفعه المصرف المقترض للمقرض ( المودِع ) ، وقد قرر مجمع البحوث الإسلامية في مؤتمره الثاني المنعقد سنة (ه 9 (م) أن : " الفائدة على أنـواع القـروض كلهـا ربـا محرم لا فرق في ذلك بـين القرض الاستهلاكي والقرض

الإتتاجي ؛ لأن نصوص الكتاب والسنة في مجموعها قاطعة في تحريم النوعين " ( ). ثالثاً : الودائع الاستثمارية في المصارف الإسلاهيية : يختلف تكيف الودائع الاستثمارية بنوعيها في فقهـ المعاملات المالية الإسـلامية المعاصرة عنه في القانون . 
فالمصرف الإسلامي يقبل هذه الودائع الثابتة والاذخارية من عملائه على أساس

المضاربة الثرعية ، ويدفع لهم ربحاً في نهاية كل سنة ، فالمصرف الإسلامي حينما

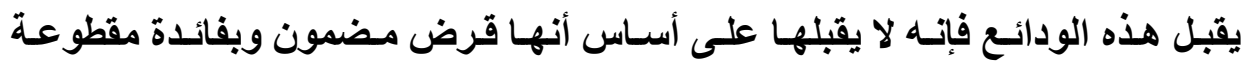
ومحددة مسبقًا ، و إنمسا يقبلها على أسساس أنها مضاربة تخضع للربح و الخسارة . فالأرباح التي تتحقق للمصرف من تلكت الودائع توزع بين المودعين والبنك باعتباره مضارباً، فما يحصل عليه المودع من ريع يكون ربحاً استحقه عند ظهور الأرباح في نهاية السنة المالية ، فليست نسبة مقطوعة على رأس المال ، و إنما هي نسبة مضافة إلى الربح الناتج ، والعائد المتحقق بعد خصم المصروفات المتعددة ('). ولا شك أن هذه المعاملة جائزة على أسساس المضاربة المشروعة ، فـلودائع بهذا التكييف مع تو افر شروط المضاربة الثرعية عمل مشروع (") 


\title{
المبحث الثاني \\ مكم الإيداعات المصرفية
}

\author{
وفيه أربعة هطالب : \\ المطلب الأول : جوائز الإيداعات المصرفية وصورها . \\ المطلب الثاني : حكم الجوائز على الحسابات الجارية . \\ المطلـب الثالـث : حكـم الجـوائز على حسـابات التـوفير الاسـتثماري والودائسع

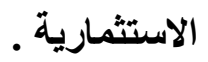 \\ المطلب الرابع : حكم السحوبات على أنواع الحسابات المصرفية .
}

\section{المطالب الأول}

\section{جوائز الإيداعات المصرفية وصورها}

الجوائز التي يقدمها المصرف لأصحاب الحسابات والودائع المختلفة فيها منفعة

ظاهرة لأصحاب الحسابات والودائع المصرفية ، والمصرف إنمـا يقدم هذه الجوائز المختلفة على الحسابات والودائع لعدة أسباب ؛ منها :

أولاًا : أن يبقى صاحب الحساب مستمراً بتعامله مع المصرف ، ومستديماً ولاءه له.

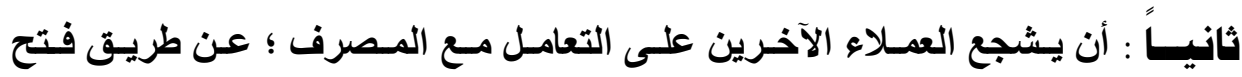

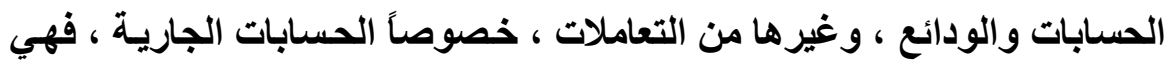


إيداعات من غير تكلفة على المصرف وجميع ربحها للمصرف .

ثالثاً : لتقديم خدمات تنافسية يتميز بها المصرف عن باقي المصارف . وحقيقـة هـذه الجـوائز هـي عطايـا مجانيـة يقـدمها المـصرف بأشـكال متعـدة لأصحاب الحسابات المختلفة والودائع المقررة .

فتـارة تكون بمبـالغ نقديـة على الحسابات المتعددة وخصوصاً الجـاري منهـا ، وتارة تكون بهدايا عينية تقدم لأصحاب الحسابات والودائع ، وتارة بدخول السحب على جوائز متعددة منها النقدي ومنها العيني ، وتارة بالاستخدام للبطاقات أو أجهزة الصرف الآلي على هذه الحسابات ، وتارة برحلات مجانية وتذاكر سفر يقدمها المصرف . ونــكر على سبيل المثـال مـا عرضـهـ المـصرف الإسـلامي الـدولي للاسـتثمار والتنمية في جمهورية مصر العربية حيث جاء في عروضهه : يقدم المصرف الخدمات المصرفية المعتادة والموجودة بكافة البنوك ، كما يتميز المصرف أيضاً بتقديم الخدمات

\section{جوائز الهج والعمهرة}

يستفيد مـن جـوائز العمـرة والحـج أصـاب حسابات الاسـثثمار ، والحسـابات الجاريـة ، ودفـاتر الادخـار بأنواعهـا المختلفـة ، وأصـحاب شـهادات الإيـاع الإسـلامية بالجنيه المصري والدولار الأمريكي .

يـخل السحب على الجوائز المودعون من الأفراد الطبيعيين فقط لمن يحتفظ

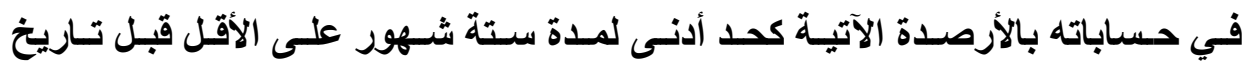

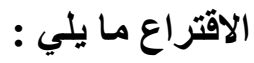




\begin{tabular}{|c|c|c|}
\hline نوع الحساب & جنيه & ل الدور \\
\hline استثمار & r... & $10 \ldots$ \\
\hline جاري & $r \ldots$ & $1 \ldots$ \\
\hline دفتر ادخار عام & $r \ldots$ & $1 \ldots$ \\
\hline دفتر ادخار عمرة & $1 \ldots$ & $\mu$ \\
\hline دفتر ادخار حج & $r \ldots$ & 9. \\
\hline
\end{tabular}

يشترط للشهادة التي تخل السحب أن تكون قد استحق أول كوبون لها ، وبحد أدنسى ألف جنيهه مصري ، أو . . ب دولار أمريكي ، سـواء كانت القيمـة تمثل شـهادة واحدة ، أو عدة شهادات .

لا يستفيد من السحب المتعاملين السابق فوزهم برحلات العمرة أو الحج ضمن أفواج المصرف ؛ لإتاحة الفرصة لغير هم ـ

تكرار إدخـال الحساب الواحد في السحب بعدد جـوائز الحد الأدنى ، على ألا يستفيد المتعامل إلا بجائزة واحدة .

يستفيد من السحب الفائزون المقيمون خـارج الوطن ، وذلك بمنحهم الحق في التنازل عن الجائزة إلى أحد الأقارب من الدرجة الأولى .

في حالة رغبة المستفيا من جائزة الحسج أو العمرة في التأجيل يقتصر تأجيل الاستفادة لمدة عام واحد فقط ، يسقط بعدها حقه فيها ـ وتحول قيمتها إلى صندوق الزكاة بالمصرف ، إلا إذا أبدى الرغبة في التأجيل . ولقد أوردت هذا العرض ؛ للتمثيل على أشـكال ونمساذج وشـروط بعض تلك الجوائز ؛ ليتصور القارئ الكريم أشكال هذه الجوائز ـ 


\section{المطاب الثاني \\ حكم الجوائز على الصسابات الجارية}

قبل الكلام على حكم الجوائز التي يقدمها المصرف لأصحاب الحسابات الجاريـة

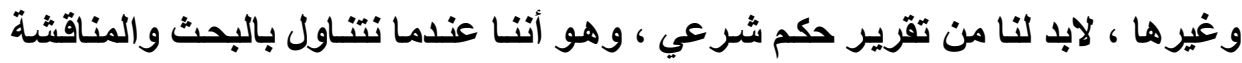

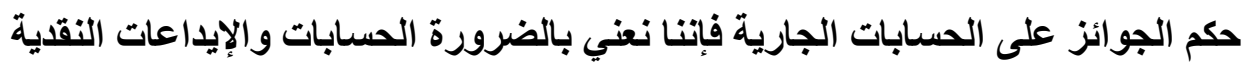

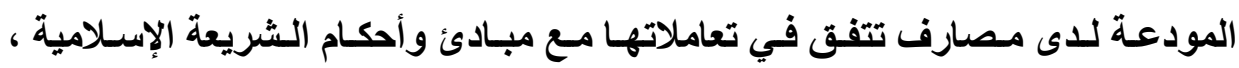
ونستبعد تلك الأموال المودعة لاى البنوك التقليدية التي يقوم نظامها الأساسي على فئى القرض والإقراض بفائدة ، والإيداعات في هذه البنوك التقليديـة غير جـائز ؛ لأنـه

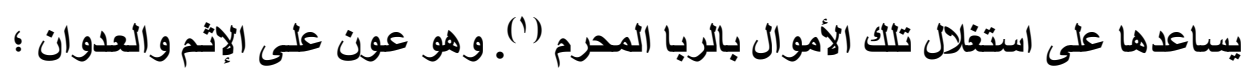

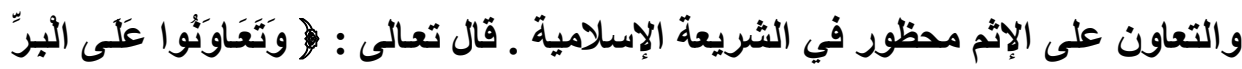

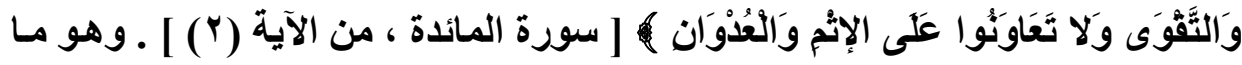

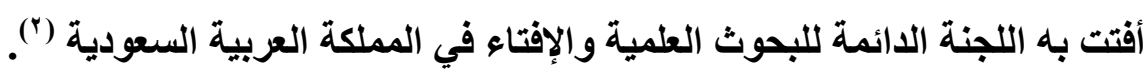
هذا في الحسابات الجارية ، وأما في الودائع الآجلة بنوعيها فهي قروض ريوية

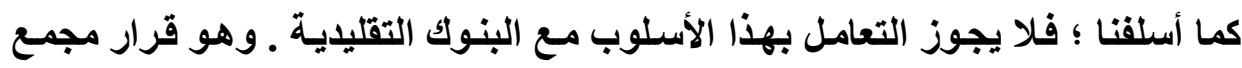

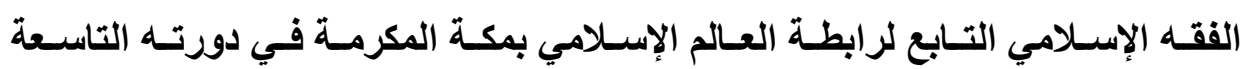

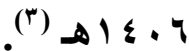
وعلى ما تقدم فإني أقدم حكم هذه الجوائز على الحسابات الجارية في المصارف

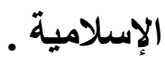

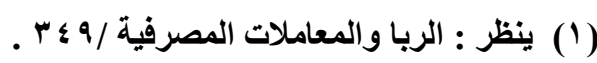

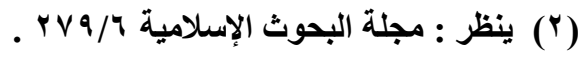

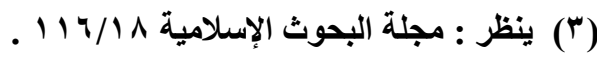


ولأجل بيان حكم هذه الجوائز ، لابد من التفرقة أولاً بين من يفتح هذا الحساب

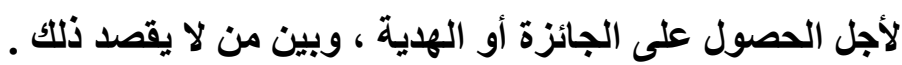

فبإذا كان القصد هو الحصول على تلك الجوائز وليس له غرض غير ذلك ؛

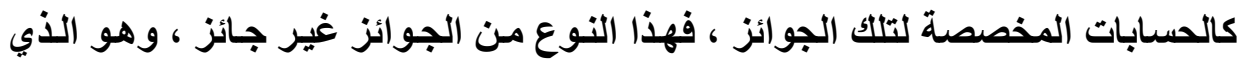

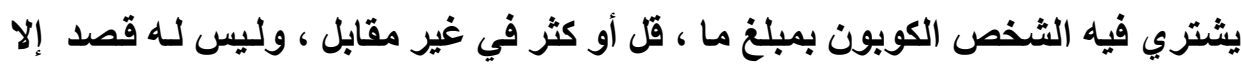

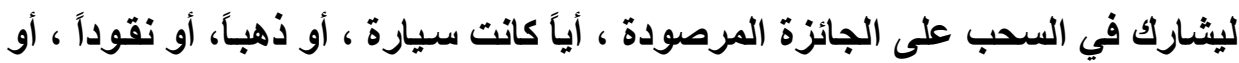

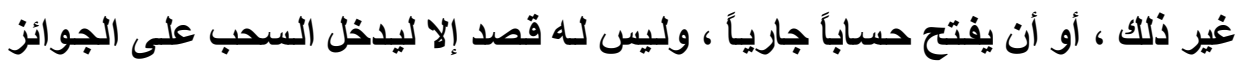

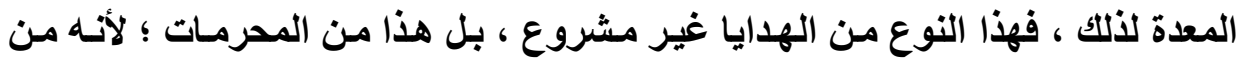

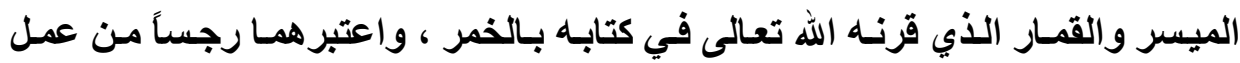

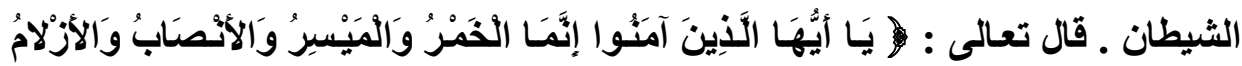

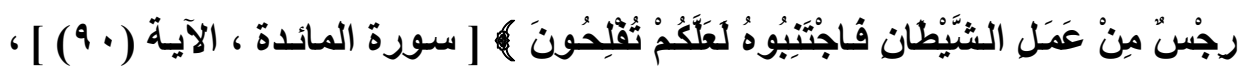

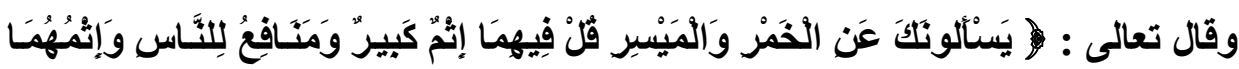

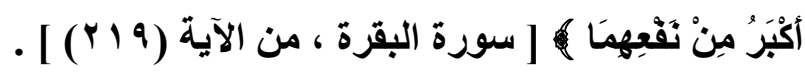
إن الثريعة الإسلامية حرمت هذا الميسر؛ لأنه يعوّد الناس ابتفاء الكسب بغير

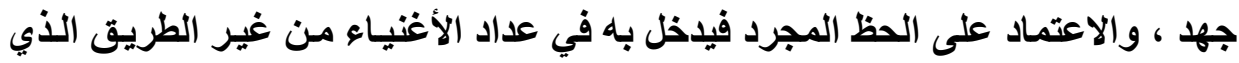

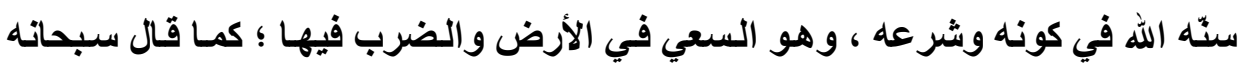

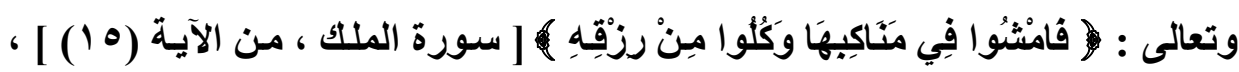

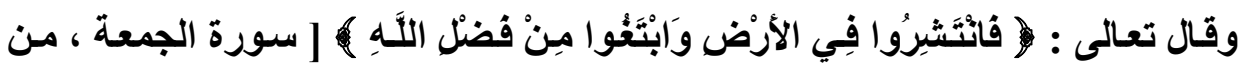

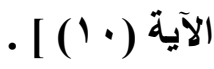
و الإسلام لا يقبل الوصول إلى الخير بالثر ، وهو حريص دائماً على شرف الغاية، وطهر الوسيلة ، ولا يرضى إلى تحقيق الغاية الشريفة ، إلا بالوسيلة النظيفة ؛ فهو الهو يرفض مبدأ " الغاية تبرر الوسيلة ". وطيلة الحئ 
وفي الحديث الشريف يقول النبي ئس : ( إن الله طيب لا يقبل إلا طيبًا )('). وأما إذا لم يكن قصد العميل هذه الجـائزة ، وإنمـا فتح الحساب الجـاري لحاجته في تعاملاته فما الحكم حينئذٍ ؟ سبق أن ذكرنـا في التكييف القـانوني والفقهي لهذه الحسابات الجاريـة بأنها قروض على المصرف قبل العميل ، فهل تعتبر هذه الهايا من قبيل المنفعة فتدخل تحت منع القاعدة : " كل قرض جر نفعاً فهو ربا " ، وعليه فهذه الجائزة نتجت عن القرض فتكون محرمة ، أو لا ؟ ولعل المسألة يعتريها الاحتمالان : الإلحاق وعدمه ، ولذا وجب كرهب

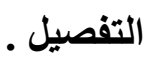

فنقول : إن اعتبرنا الحسابات الجارية قروضاً ، فلا خلاف بين الفقهاء ()، على أنه لا يجوز اشتراط زيادة في بلل القرض للمقرض ، وأن هذه الزيادة ربا ، ولم يفرقوا

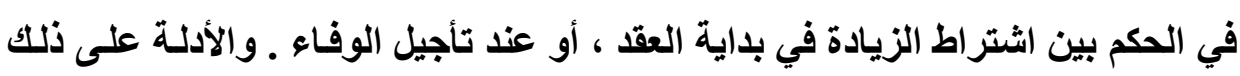
تطلب في مظانها (") وعلى هذا ؛ فإذا اعتبرنا الحساب الجاري قرضاً ، واشترط في عقد فتح الحساب الجاري ، أو في أثنائه ، أو عند إققاله حصول المقرض على هدية أو جائزة ؛ فبان ذلك يعتبر ربا محرم .

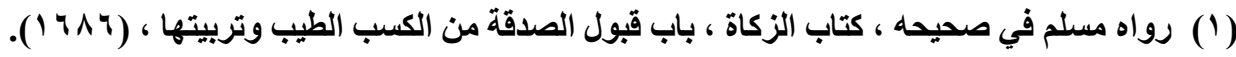

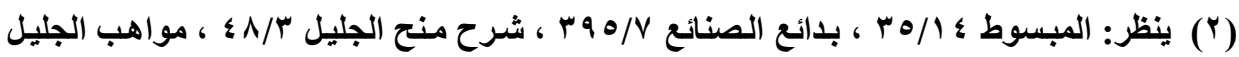

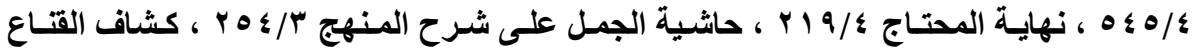
ا

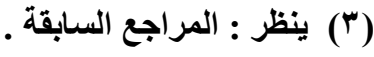


وأمـا إذا لـم يكن هنـاك شـرط عند فتح الحساب الجـاري ، وقدم المصرف هذه

الجوائز والهدايا دون شرط مسبق ، فما الحكم حينئ ؟

للإجابـة عن هذا التساؤل لابــ من عرض تأصيلٍ فقهي لمسألة مشهورة في الفقه، وهي حكم المنفعة المادية غير المشروطة في القرض .

وهذه المسألة لها حالان :

الحسال الأولى : الزيـادة عند الوفـاء مـن غير شـرط ، مـع الاختلاف في التقييـا

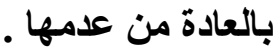

وقد اختلف العلماء في هذه المسألة على ثلاثة أقوال : الجواز ، والتفصيل بين

الزيادة في الصفة وغيرها، والمنع ، وتفصيل الأقوال والأدلة يطلب في مظانها (').

ولعل هذه الحال غير منطبقة على ما نحن بصدده ، حيث إن المصارف لا تعطي

جوائز لمن يغلق وينهي الحسابات الجارية ، بل على العكس ، فقكرة هذه الجوائز إنمـا هي لاجتذاب رؤوس الأموال إلى المصارف، وبالتالي لن نخوض في بيان هذه المسألة . الحسال الثانيـة : وهي الزيـادة الماديـة غير المشروطة قبـل الوفـاء ، ولعل هذه الحال هي التي تنطبق على مسألة بحثنا، ولذا اقتضى البيان ؛ فإذا بذل المقترض منفعة غير مشروطة أثناء مدة القرض - قبل الوفاء - مثثل : الهـيـة للمقرض ، فقد اختلف هـ الفقهاء في حكمها إذا كانت من غير شرط ، على قولين : القول الأول : التحريم ما لم يدل دليل على أن المنفعة ليست من أجل القرض ؛ 
أي ليس سببها القرض وإنما سببها أمر آخر ، كمـا لو كان ذلك شيئًا جرت بـه العـادة بينهما قبل القرض ، أو حلث سبب موجب للإهداء ، ونحوه بعد القرض ، ممـا لا يكون سبيه القرض ، إلا أن يكافئه عنه المقرض ، أو يحسبه من دينه . وهو قول المالكية والمذهب عند الحنابلة ('). القول الثاني : الجواز ، وهو قول الحنفية والثافعية ورواية عن أحمد ().

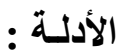

\section{أ - أدلة قول المنع (")}

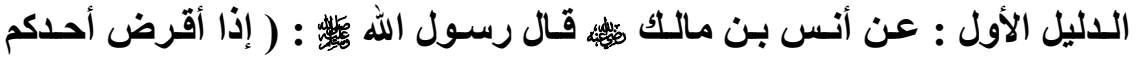

قرضاً فأهدى إليه ، أو حمله على الدابة فلا يركبها ولا يقبله ، إلا أن يكون جرى بينه وبينه قبل ذلك ) (؛).

وجه الالالة : يـل الحديث على النهي عن قبول هدية المقترض ، أو الانتفـاع بدابته أثناء مدة القرض ، إلا أن يكون ذلك جارياً بينهما قبل القرض ، فيجوز .

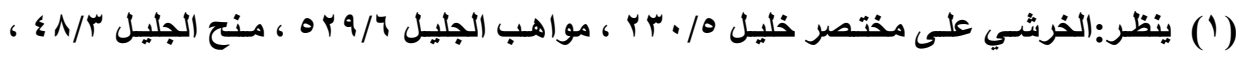

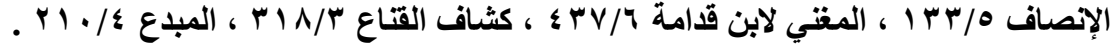

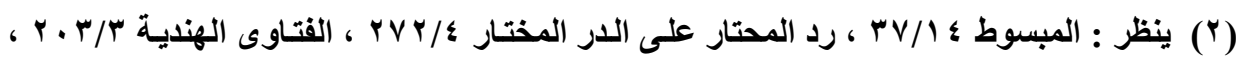

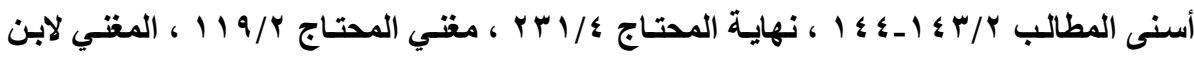

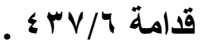

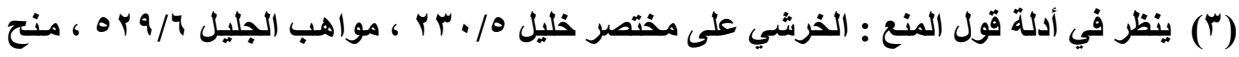

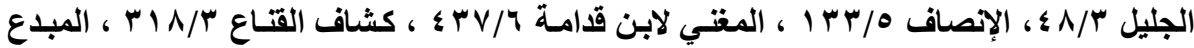


الدليل الثاني : الآثار الواردة عن الصحابة الدالة على المنع من قبول هدية

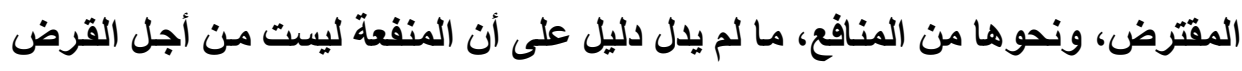
، إلا أن يكافئه عنها المقرض ، أو يحسبها من دينه .

ومنها ما روي عن ابن سيرين قال : " تسلَّف أبيّ بن كعب من عمر بن الخطاب مالاً ـ قال : أحسبه عشرة آلاف ـ ، ثم إن أبيّا أهدى لله بعد ذلك من تمرتـه ، وكاتت

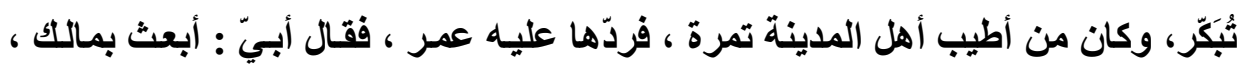

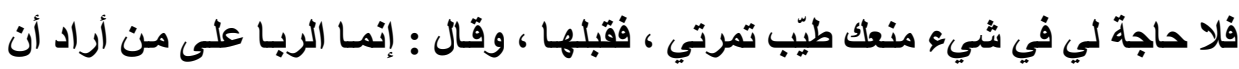
يربي وينسيء " (')

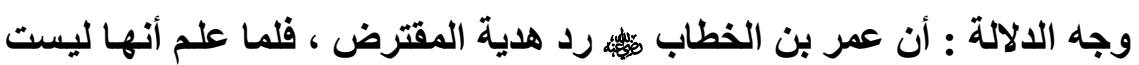

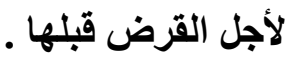
(") أدلة قول الجواز (")

استدل من قال بالجواز بقول النبي وجه الدلالة : أن الحديث عام في حسن القضاء سواء كان ذلك قبل الوفاء أو بعده. وقالوا : إن هذه الزيادة غير مشروطة في العقد ، فلا مانع شرعاً منها (؛).

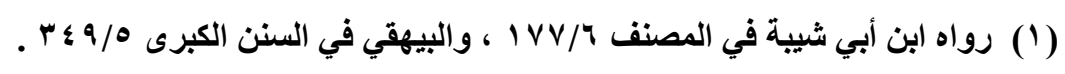

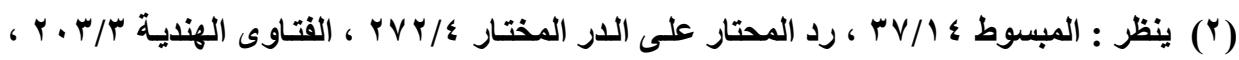

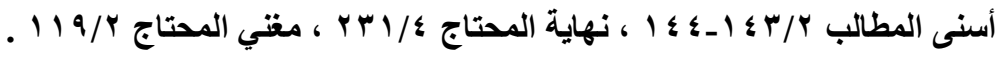

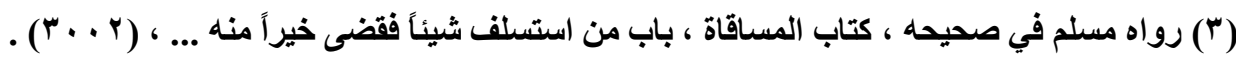

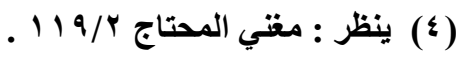


لاثشك أن المسألة المذكورة قد تناولها العلمـاء قديماً وحديثاً ، بحثًاً وحكمـاً ،

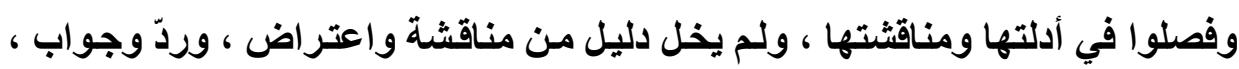
وبعد استعراض المسألة بشكل موجز ، يتبين أن المسألة على ثلاث أحوال (')

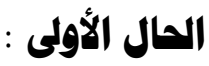

أن يعلم أن المنافع الواقعة قبل الوفاء إنما هي لأجل القرض ، أو أن تدل القرائن

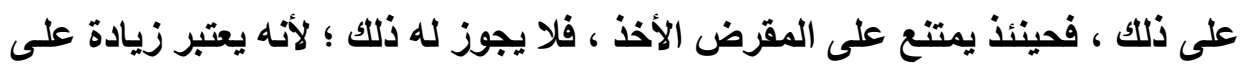
القرض ، والزيادة على القرض ممنوعة شرعاً .

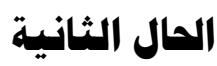

أن يعلم أن المنـافع الواقعـة قبل الوفـاء ليست مـن أجل القرض ، أو أن تـلـل القرائن على ذلك ، كما لو كانت العادة جارية بينهما بذلكك قبل القرض ، فهذه جائزة ،

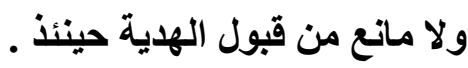

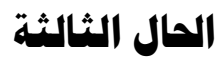
ألا يوجد شيء من ذلك مما يدل على أحد الأمرين ، فعلى هذا تمنع عند أصحاب القول الأول ، حتى يتبين أنها ليست من أجل القرض ، وتجوز عند أصحاب القول

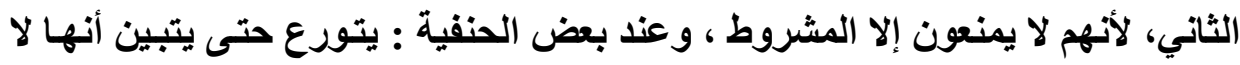

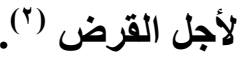


والمسألة تتجاذبها الأقوال والاختيارات ، وإني أختار قول الحنفية والثافعية في ذلك ، وهو الجواز ؛ لكن بشرط أن لا يكون ذلك في مقابل القرض ، وليس من أجله ؛ وذلك لعموم الأدلة القاضية بحسن الأداء ، وعدم الشرط في أصل العقد ـ والله أعلم . فإذا ما طبقنا هذا الحكم على مسألة الجوائز والهـايا على الحسابات الجاريـة ، فإن هذا الخـلاف ربمـا ينعكس على مسألتنا ، فمـن يقول بـالمنع ، لا يجيز مثل هذه الجوائز والهدايا ، وبناء على هذا القول فإن الجوائز التي يقدمها البنك ـ المقترض لأصحاب الحسابات الجاريـة ـ المقرض - لا تجوز ، لأن البنـك يقدمها لهم في أثنـاء تعاملهم معه ، وهي متكررة ومعروفة للمتعاملين مع البنك ، فهي في حكم الرشوة ، أو

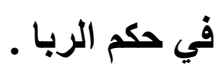

وقد يقـال : إن الهدف من تقديم هذه الجوائز هو بقاء المتعـاملين مـع البنك ، وجلب متعاملين جدد ، وفي هذا مصلحة عامة كما لا يخفى !! والجواب عليه من وجهة نظر المانع : أن المصلحة وإن كاتت مصلحة ظاهرة ، فإنه لا يجوز التوصل إليها بوسيلة محرمـة ، ومن المقرر أن الشارع لا يمنع وسيلة محرمسة توصـل إلى مسصلحة ظـاهرة إلا جعل لهـا وسـيلة مسروعة توصـل إلى تلـك المصلحة الحقيقية .

وأمسا مـن يقـول بـالجواز ، فيقول بجـواز هذه الجـوائز والهـدايا التـي تقدمها المصارف لأصحاب الحسابات الجاريـة إن كاتت غير مشروطة في عقد فتح الحساب الجاري، وهذا هو الذي اختاره ، لاقتصار المنع على الاشتراط فقط ، وإلا فيقى على

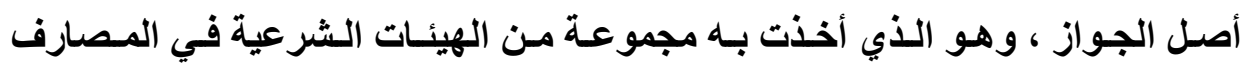
الإسلامية ، وأذكر منها على سبيل المثال : 
ا - فتوى الهيئة الشرعية لبنك فيصل الإسـلاهي السوداني - فتـوى رقسم (IIrA)

\section{ونص السؤال والجواب ها يلي :}

نتساءل عمـا إذا كـان جـائز للبنك منح جوائز للمدخرين فيه وهم لا يعلمون ، أو

يتوقعون أية حوافز عند فتحهم حسابات الادخار ؟

الجواب : يجوز أن يمنح البنك جوائز لأصحاب ودائع الادخـار دون علم سـابق من جانبهم ، ولكن لا يحددها البنك ؛ بحيث تتعدد وتتباين صور هذه الجوائز في كل مرة ،

ولا تكون في فترات ثابتـة حتى تصبح هي الدافع للادخـار ، ولا يجوز تقديم جوائز للمدخرين بصورة معلنة ومتكررة ، وإن كانت غير مشروطة في عقد وديعة الادخار ؛ لأن ذلك سيصير بمرور الزمن عرفاً ، وبالتالي يأخذ حكم المنفعة المشروطة في عقد

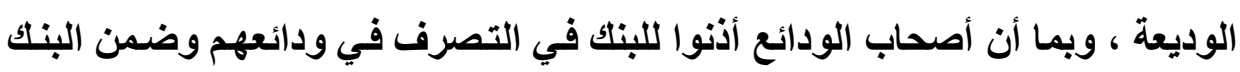
ردها إليهم ، فإنها تأخذ حكم القرض ولا يجوز اشتراط منفعة للمقرض . r- فتوى هيئة الفتوى والرقابة الشروية لبيت التمويل الكويتي رقم (199) : ونص

\section{السؤال والجواب ها يلي}

السؤال : هل هنـاك من حرج شـرعي في الإعلان عن منح بعض الهـايا مثل

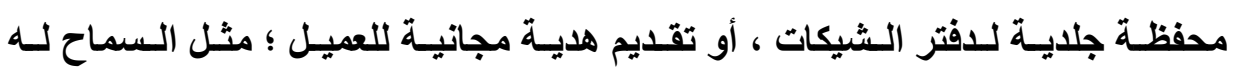
باستخدام صندوق حديدي للأمانات ، في حين نتقاضس مقابل هذه الخدمة رسوماً في العـادة ، أو إعطاء العميل بطاقة موقف مجانيـة ، أو إجراء قرعة تـذاكر سـفر وإقامـة لأداء العمرة ، وذلك لأصحاب الحسابات الجاريـة التي تكون أرصدتها تزيــ عن مبلغ 
الجواب : لا مانع من الناحية الثرعية في الإعلان عن منح بعض الهايا لأصحاب

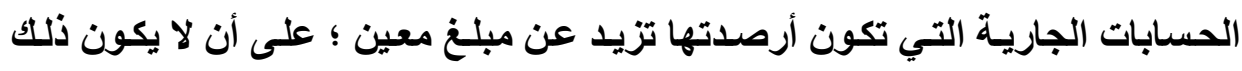

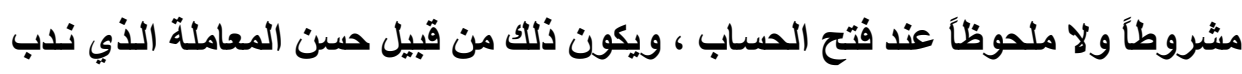

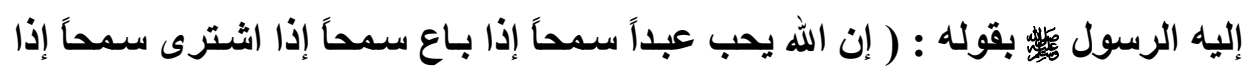
(1) (1قضى )

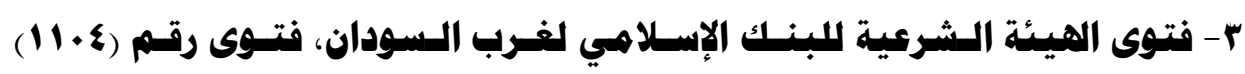
ونص السؤال والفتوى هما يلي :

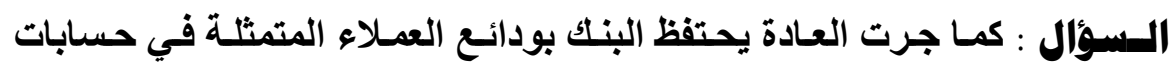

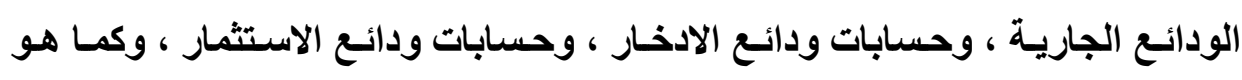

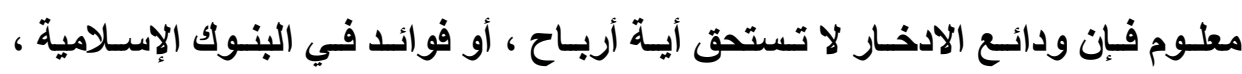

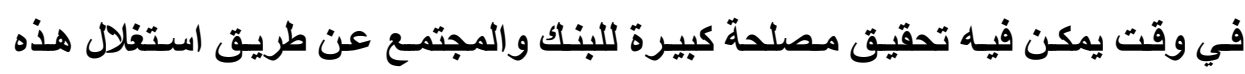

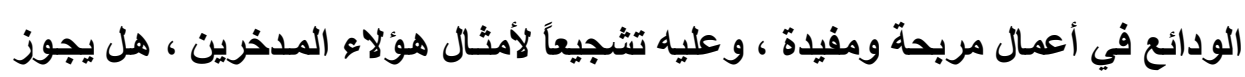

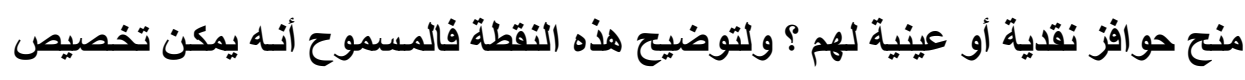

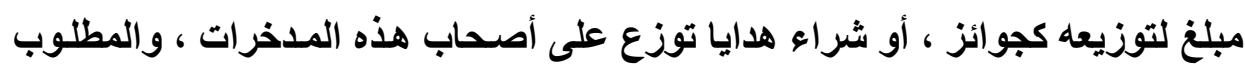

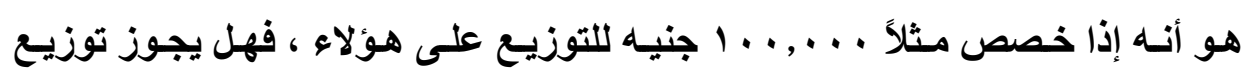

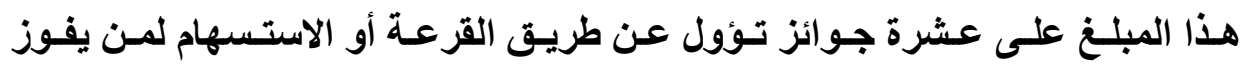

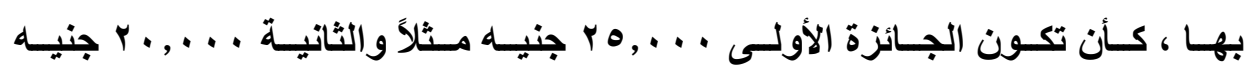
وهكنا؟

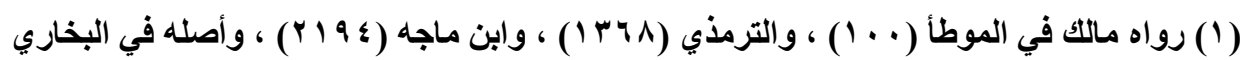
. (Y.V )

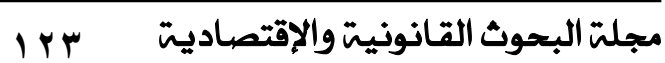


الجواب : إن ودائع الاذخار تعتبر وديعة عند البنك ، وأجاز بعض الفقهاء الاتجار

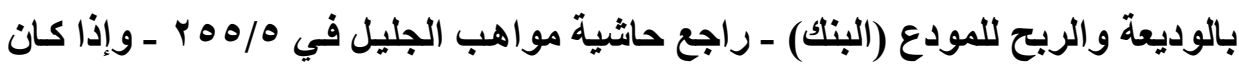

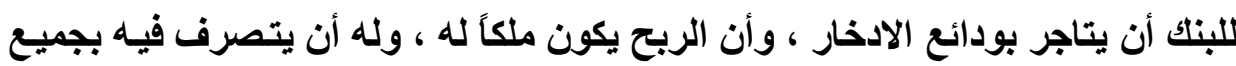

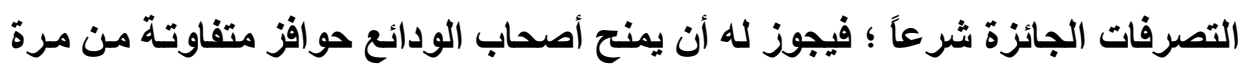

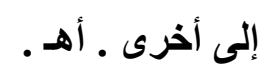

وبعد هذا السرد لعدة فتاوى لهيئات شرعية لمصارف إسلامية ، فالقول بالجواز

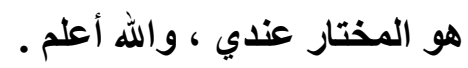

إلا أنسه ينبغي أن يراعى مـع القول بجواز مثل هذه الجوائز والهـايا بأثكالها

$$
\text { المتعددة على الحسابات الجارية عدة أمور : }
$$

1- أن تكون الهدايا والجو ائز ممـا تجوز شرعاً ، ويمكن الاتتفاع بها انتفاعـاً

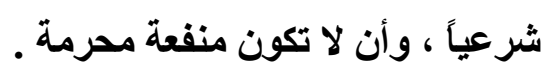

r- أن لا يكون هناك شرط مكتوب أو ملحوظ عند فتح الحساب الجاري بالتزام المصرف لهذه الهايا ، و إلا اعتبرت قرضاً جر نفعاً ، وهو محرم.

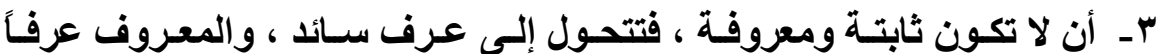

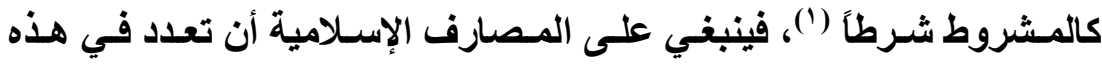
الجوائز ، وأن لا تحددها مسبقاً ، وأن تتباين صور ها في كل مـرة ، زيـادة

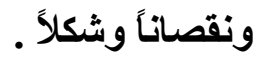




\section{المطب الثالث}

\section{هكم الجوائز على هسابات التوفيز الاستثـماري والودائع الاستثـمارية}

ذكرنـا فيمـا سـبق أن الإيــاعات الثابتـة لأجلـل ، وودائسع الادخــار الاسـتثمارية

(حسابات التوفير) ، في المصارف الإسـلامية عبارة عن عقد مضاربة بين المصرف والعميل ، وليست ودائع بالمعنى الدقيق .

وحسـاب الاسـتثمار أو الوديعـة هـو رأس مسال مـضـاربة ، تطبق عليـه أحكـام

المضاربة ، ومن أحكام المضاربة المتفق عليها ('):

أ - أن رأس مال المضاربة مملوك لرب المال ، وهو أمانـة في يـ المضارب ؛ لا

يضمنه إذا هلك من غير تعد ولا تقصير منه .

ب - أن الربح يستحقه رب المسال نظير مالـه، ويستحقه المضارب نظير عمله، ويجب أن يكون نصيب كل من رب المال والمضارب مقداراً شـائعاً في الربح؛ كأن يكون الربح بينهما مناصفة ، أو يكون للمضارب ؟٪\% ولرب المـال ونحو ذلك ـ ولا يجوز اشتراط مبلغ معلوم لأحدهما .

جـ أن الخسارة يتحملها رب المال في مالـه ، والمضارب في عمله ، ولا يشارك المضارب رب المال فيما ضاع من ماله ، كما لا يشاركه رب المسال فيمـا ضـاع من عمله وجهده . 
وبناء على هذه الأحكام فإن الجوائز التي تقدمها المصارف لأصحاب الحسابات الاسـتثمارية ـ أربـاب المـال - جـائزة مـا لـم تتعـارض مـع حكم مـن أحكـام المـضاربة السابقة، وهناك أحوال يتصور فيهما التعارض فلا تجوز فيها الجوائز والهايا وهي : أ - إذا ترتب على الجـوائز شـبهة ضـــان المـصرف ـ المـضارب ـ لأصـحاب حسابات الاستثمار - أرباب المـال ـ رأس مـالهم أو مشاركتهم في الخسارة ؛ كأن يقدم المصرف هذه الجوائز في الحالات التي تكون فيها خسارة في مسال

$$
\text { المضاربة. }
$$

ب ـ إذا ترتب على الجـوائز شـبهة التزام المـصرف ـ المـضارب ـ لأصسحاب حسابات الاستثمار - أرباب المال ـ مبلغاً محدداً ، أو نسبة محددة من رأس مالهم ، كأن يقدم المصرف هذه الجوائز في الحسالات التي تكون فيها الأربـاح متدنية ، فيعد المصرف إلى زيادتها بهذه الجوائز للمحافظة على عملائه . جـ أن لا يشترط في عقد فتح الحساب هذه الجـائزة ، أو الهـيـة ، فهذا الشرط ينافي أحكام المضاربة كما سبق بيانه، فهي زيادة مقرة على الربح ، معلومة تنافي مبدأ المشاركة في الربح ، ومن شروط صحة المضاربة تحديد النسبة ، لا القدر المعين المحدد . فإذا لم يشترط ، بل يكون ذلك كحافز لفتح هذا النوع من الحسابات فلا مـانع شرعي من ذلك . وفي ما عدا ذلك فلا مـانع من تقديم هذه الجوائز والهدايا لأصحاب الحسابات الاستثمارية ، وذلك لتحقيق الإبقاء على العملاء وجلب المزيد منهم . 
ولعل الجوائز والهدايا على الحسابات الاستثمارية أخف شبهة وخلافًَ مـن

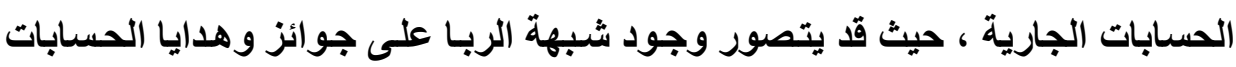
الجارية، أما في الحسابات الاستثمارية على التكييف الثرعي لها ؛ وهي المضاربة ،

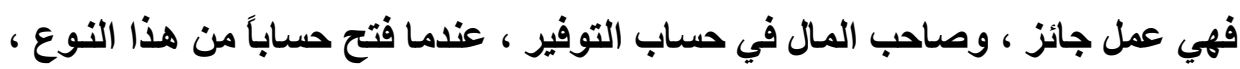
لم يتوقع من المصرف شيئًا غير الأرباح الشرعية المحققة، ولم يفرض لنفسه حقاً زائداً على ذلك ، فإن تبرع المصرف بها ، فلا إثكال شرعي في ذلك ، وقد سبق في نص فتوى الهيئة الشرعية للبنك الإسلامي لغرب السودان رقم (ـ ـ 11 ) إجازة مثل هذا

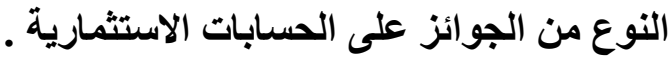
وسبق أيضاً نص الفتوى لبنك فيصل الإسلامي السوداني والتي أجازت مثل هذه الجوائز والهايا لأصحاب ودائع الادخار .

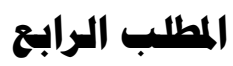 \\ حكم السحوبات على أنواع الحسابات المرفيـة \\ السحب على الصساب نوع هن أنواع القرعة :}

و القرعة في اللغة : السهمة والنصيب ، والمقارعة : المساهمة ، وأقرعت بين الثركاء في شيء يقسمونه ، ويقال : كانت لله القرعة ، إذا قرع أصحابه ، وقارعه فقرعه يقرعه : أي أصابته القرعة دونه (') 
ولا يخرج المعنى الاصطلاحي عن المعنى اللغوي ، قال البركتي : القرعة السهم

والنصيب ، وإلقاء القرعة : حيلة يتعين بها سهم الإنسان أي نصيبه (')

فهي اصطلاحاً : تمييز الحصص بعضها من بعض (r).

والصلة بين القسمة والقرعة ؛ أن القرعة طريق من طرق القسمة ، والقرعة نوع

من أنواع القسمة عند المالكية (").

الهكم الشرعي للقرعة :

القرعة مشروعة باتفاق الفقهاء (؛)، وقد تكون مباحة ، أو مندوبة ، أو واجبة ،

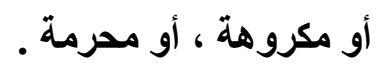

\section{وثبتت هشروويتها بالكتاب والسنة}

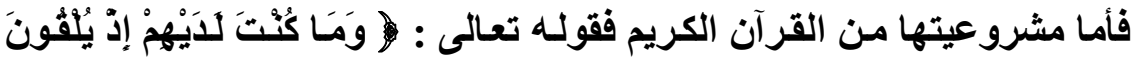

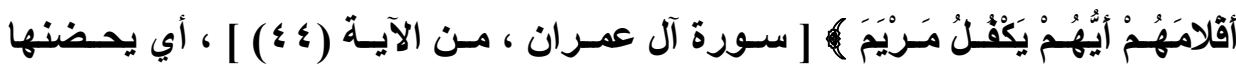

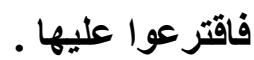
وأمسا مشروعيتها من السنة المطهرة فحديث أبي هريـرة فئه قـال : ( عرض

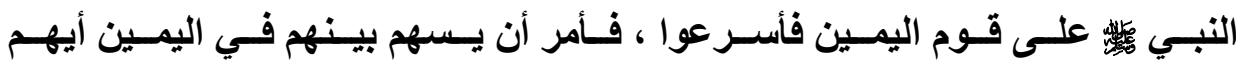
يحلف ) (0)

(1) ينظر : الموسوعة الفقهية الكويتية س// با ـ .

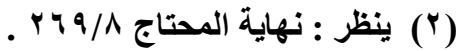

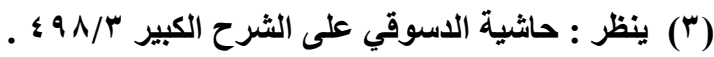

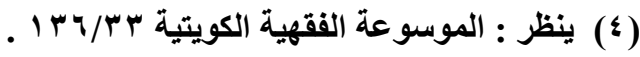

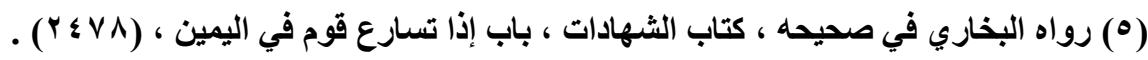




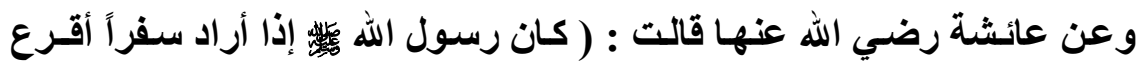

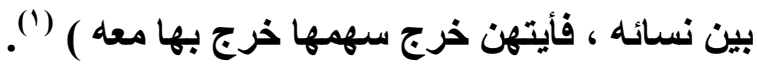
و الحكمة من مشروعيتها ؛ لتطيب القلوب بين المتنافسين .

قال المرغيناني : القرعة لتطييب القلوب ، وإزاحة تهمة الميل ، حتى لو عين

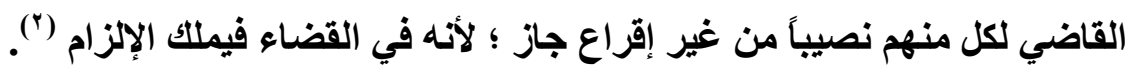

فالقرعة في الأصل جائزة ، إلا في بعض المواطن التي يمتنع فيها القرعة (").

ومما يتصل بموضوع بحثنا هو القرعة في العطاء ، فقد نص الشافعية على

القرعة في الغنيمة في مواضع منها :

أ ـ ما نقله النووي عن الماوردي فيمن يقدم - عند العطاء ـ فقال : يقلم بالسابقة

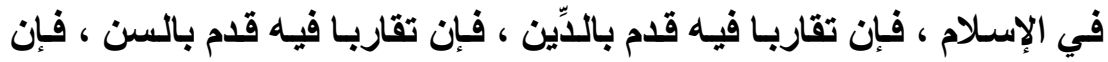

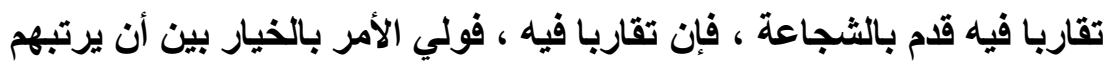

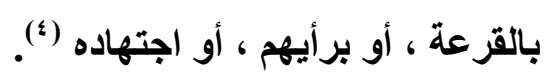

ب - ما نقله الرملي في قسمة الغنيمة حيث يخرج منها السلب ، والمؤن اللازمـة للأجور والحفظ وغيرها ، ثم يجعل الباقي خمسة أقسام متساوية يجري فيها

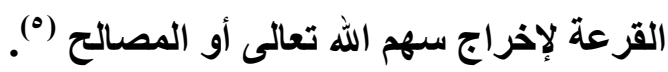

(1) رواه البخاري في صحيحه ، كتاب الهبة ، باب هبة المرأة لغير زوجها ... ، (ع ـ ؟ ب) .

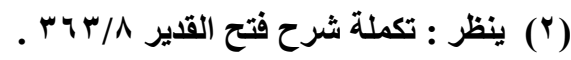

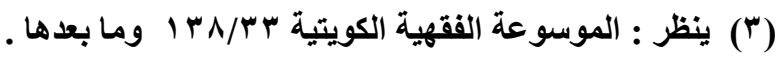

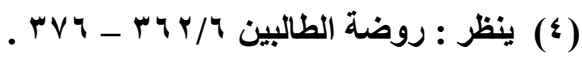

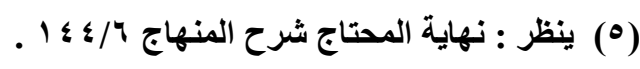

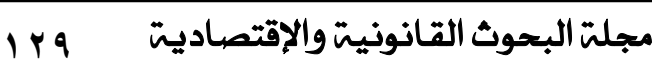


وعلى ما تقام من جواز القرعة فلا مـانع شرعي من استخدام أسلوب القرعة

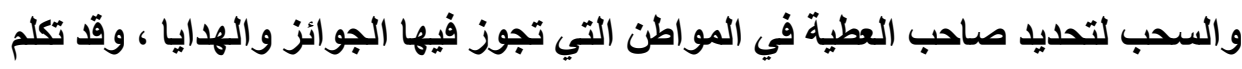
الفقهاء عن كيفية إجراء القرعة ، وكيفية إجرائها ـ

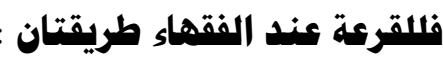
الأولى : كتابة أسماء الثركاء في رقاع ، ثم تتم القرعة .

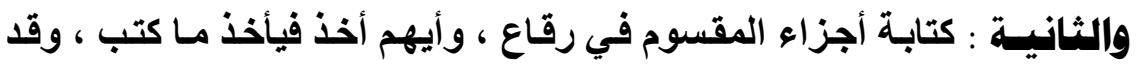

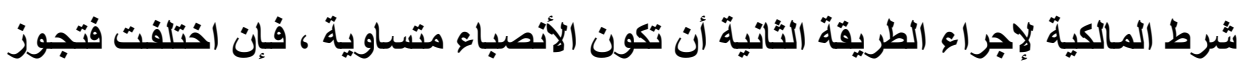
في العروض خاصة (') وقد أجـاز كل مـن الشافعية والحنابلـة إجراءهـا في الصورتين ، إلا أن طريقة كتابة الأسماء أولى عند الثافعية (†). ولا مانع من اتخاذ أي وسيلة أخرى بشرط أن لا تعارض حكماً شرعياً مقرراً . 


\section{الخـاتمسة}

وفي ختام هذا البحث حول حكم جوائز الإيداعات النقية لاى المصارف ، تبين

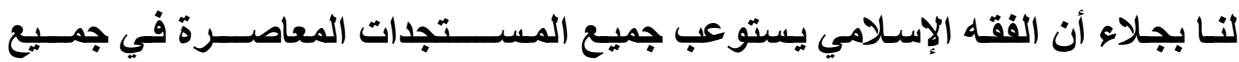

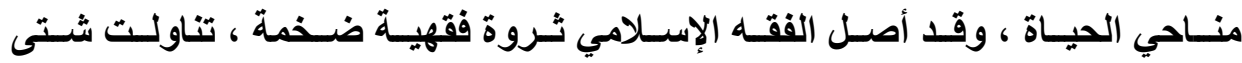

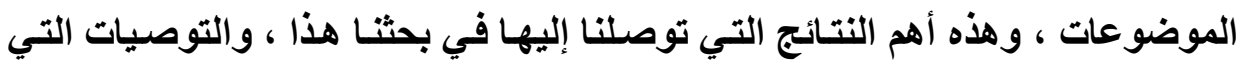

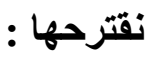

1- الجائزة في اللغة : هي العطية مطلقاً ، ولا يخرج معناها الاصطلاحي عن معناها

$$
\text { اللغوي . }
$$

rــ القمار هو كل لعب يشترط فيه غالباً من المتغالبين شيئاً من المغلوب . r- الودائع المصرفية قـ تكون عينية حقيقية ، وقد تكون نقدية . ئ - الودائع النقدية هي النقود التي يعهد بها الأفراد أو الهيئات إلى البنك على أن يتعهل الأخير بردها وبالشروط المتفق عليها . هـ تتنوع الودائع المصرفية إلى ثلاثة أنواع رئيسة : أ ـ الودائع الجاريـة "تحت الطلب" : وهـي المبالغ التي يودعها أصحابها في

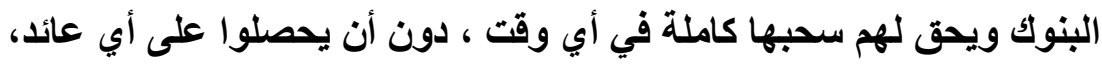

$$
\text { أو فائدة ، ويسمى بالحساب الجاري . }
$$

بـ ودائع ثابتة "لأجل" : وهي المبالغ التي يودعها أصحابها في المصرف ويدفع

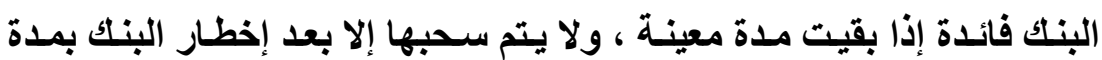

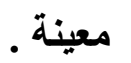


جـ ودائـع ادخـار "تـوفير" : وهي المبالغ التي يودعها أصحابها في المصرف ويحق لهم سحبها كاملة منى شاؤوا ، ويعطى أصحابها فائدة تكون في الغالب

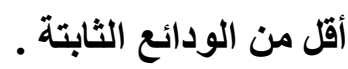

7ـ التكييف القانوني والشرعي للحساب الجاري هو القرض ، وعليه فلا يجوز أخذ

$$
\text { أي فوائد أو عوائد عليه . }
$$

V- لا يختلف التكييف القانوني للودائع الثابتة في البنوك التقليدية عن الحسابات

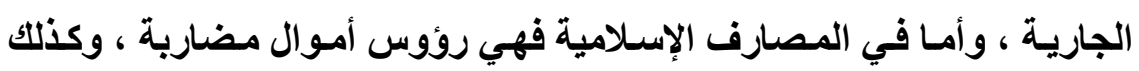

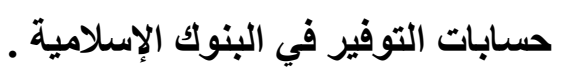

ᄉ- حقيقة الجوائز المصرفية أنها عطايا مجانية تقدمها المصارف بأشكال متعددة . 9- لا تجـوز الجـوائز على الحسابات الجاريـة إن كانـت مسشروطة في عقد فتح الحساب .

ـ 1 ـ الجوائز المصرفية على الحسابات الجارية دون شرط على ثلاثة أحوال : الهال الأولى : أن يعلم أن المنافع الواقعة قبل الوفـاء إنمـا هي لأجل القرض ، أو أن تلال القرائن على ذلك ، فحينئذ يمتنع على المقرض الأخذ ، فلا يجــوز لـه ذلكلك ؛ لأنـه يعتبر زيـادة على القرض ، والزيـادة على القرض ممنوعة شرعاً. الحالــة الثانيسة : أن يعلـم أن المنـافع الواقعـة قبل الوفـاء ليست مـن أجل القرض ، أو أن تلل القرائن على ذلك ، كما لو كاتت العادة جارية بينهما بذلك قبل القرض ، فهذه جائزة ، ولا ماتع من قبول الهدية حينئ . المالة الثالثة : ألا يوجد شيء من ذلك مما يدل على أحد الأمرين . 
و المسألة تتجاذبها الأقو ال والاختيارات ، وإني أختار قول الحنفية والثافعية

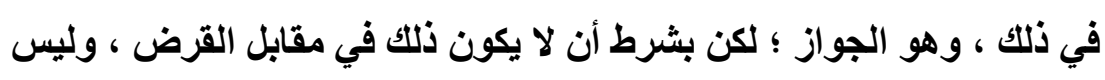
من أجله . 11 - مع القول بالجواز ينبغي أن يراعى ما يلي : أ-ـ أن تكون الهدايا والجوائز ممـا تجوز شرعاً ، ويمكن الاتتفاع بها انتفاعاً

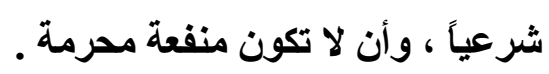
بـ أن لا يكون هناك شرط مكتوب أو ملحوظ عند فتح الحساب الجاري بـالتزام المصرف لهذه الهايا، وإلا اعتبرت قرضاً جر نفعاً، وهو محرم. ج- أن لا تكون ثابتـة ومعروفة ، فتتحول إلى عرف سـائد ، والمعروف عرفـاً

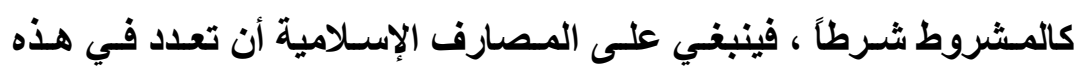

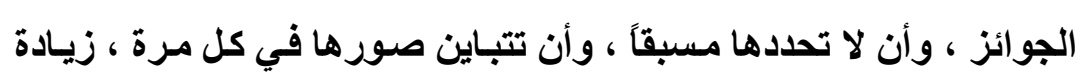
ونقصانًاً وشكلاً ووقتا.

r ا ــ الجوائز المصرفية على الحسابات الاستثمارية جائزة ما لم تتعارض مـع حكم من أحكام المضاربة الثرعية .

rا 1 ـ تتعارض الجائزة مع حكم المضاربة الثرعية فحينذذ تحرم ولا يجوز قبولها أو

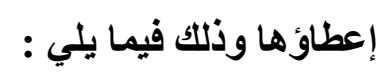

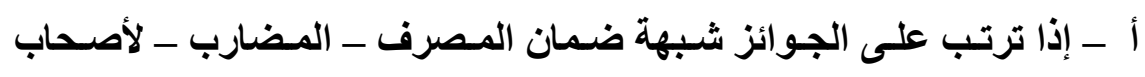

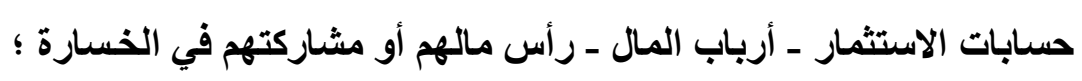
كأن يقدم المصرف هذه الجوائز في الحالات التي تكون فيها خسارة في مـال

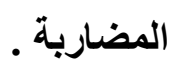


ب - إذا ترتب على الجوائز شبهة التزام المصرف ـ المضارب ـ لأصحاب حسابات الاستثمار - أرباب المال - مبلغاً محدداً ، أو نسبة محددة من رأس مالهم ، كأن يقدم المصرف هذه الجوائز في الحالات التي تكون فيها الأرباح متدنية ، فيعمد المصرف إلى زيادتها بهذه الجوائز للمحافظة على عملائه . جـ أن لا يشترط في عقد فتح الحساب هذه الجـائزة ، أو الهـيـة ، فهذا الشرط ينافي أحكام المضاربة ، فهي زيادة مقدرة على الربح ، معلومـة تتافي مبدأ المشاركة في الربح .

ع ا - لا مانع من استخدام أسلوب القرعة والسحب لتحديد صاحب العطية . كما أتقدم ببعض التوصيات ومنها : 1- السعي نحو توسيع الاستثمارات وفق أحكام الثريعة الإسلامية ؛ لجذب المتعاملين دون الحاجة لحوافز خارجية . r- تنمية الموارد الاقتصادية لدى المؤسسات المالية الإسلامية ؛ لمواكبة التطور والمنافسة الحاصلة بين المؤسسات المختلفة .

r- دراسة المستجدات المعاصرة فيما يتعلق بالقضايا المالية المعاصرة ، وعقد الندوات والمؤتمرات لذلك الغرض .

ع ـ توفير الدراسات والبحوث المتعلقة بالقضايا المالية المعاصرة فيما يتعلق بالمعاملات الشرعية ، لتسهيل الرجوع إليها والاستفادة منها . وفي ختام هذا البحث أسأل الله تعالى أن يوفقتا لما يحبه ويرضاه ، وأن يخدم بنا الإسلام والمسلمين ، والله ولي التوفيق . 


\section{ثبـت المراجـع}

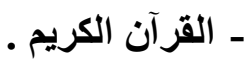

ـ أحكام الشركات في الفقه الإسـلامي ، د. يوسف عبد المقصود ـ ط ـ مطبعة الأخوة الأشقاء - القاهرة - الطبعة الأولى - • 91 ام .

ـ أساس البلاغة ، محمود الزمخشري ـ ط. دار الفكر - بيروت ( بدون تاريخ ) . ـ أسنى المطالب شرح روض الطالب ـ لأبي يحيى زكريـا الأنصاري ـ ط. دار الكتاب

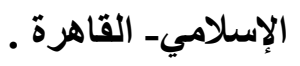

ـ الاقتصاد الإسلامي ـ د. عبد الله عبد المحسن الطريقي - مؤسسة الجريسي للتوزيع

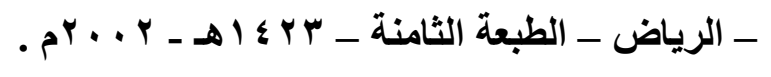
ـ الأم ـ للإمام الثافعي ـ الطبعة الثانية ـ ط. دار المعرفة - بيروت .

ـ الإنصافـ للمرداوي - الطبعة الثانية ـ ط. دار إحياء التراث العربي - بيروت . - بحوث فقهية معاصرة ـ أ.د. محمد عبد الغفار الشريف ـ ط. دار ابن حزم - بيروت

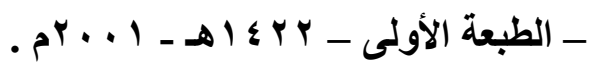
- بحوث في الاقتصاد الإسـلامي ـ د. علـي محي الدين علـي القره داغي - ط. دار

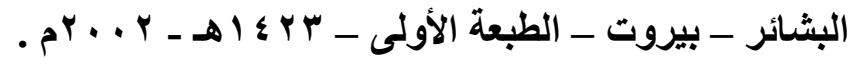

ـ بحوث في المعـاملات والأسـاليب المصرفية ـ د. عبد الستار أبو غدة - ط. بيت التمويل الكويتي . 
- بدائع الصنائع في ترتيب الشرائع لعلاء الدين أبي بكر الكاسـاني_ط. دار الكتاب

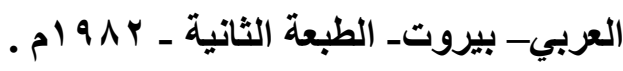

- بلغة السالك لأقرب المسالكك ـ لأحمد الصاوي ــ. دار المعارف ـ القاهرة. ـ التاج والإكليل - لأبي عبد الله محمد بن يوسف الشهير بالمواق - مطبوع بهامش

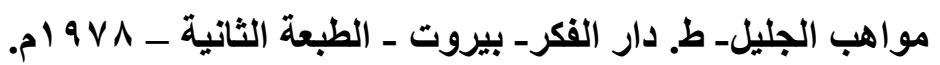
ـ تبيين الحقائق شرح كنز الدقائق ـ للزيلعي- ط. دار المعرفة - بيروت ـ ـ التعريفات للجرجاني - ط. دار الكتاب العربي - بيروت ـ الطبعة الأولى . - حاشية البجيرمي على المنهج - ط. مصطقى البابي الحلبي- مصر - 901 ام . - حاثية الجمل على شرح المنهج - سليمان الجمل - ط. دار الفكر- بيروت . ـ الخرشي على مختصر خليل ـ الشيخ سليمان الخرشي ـ ط. دار الكتاب الإسـلامي -

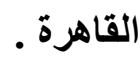

ـ دليل المصطلحات الفقهية الاقتصادية - بيت التمويل الكويتي . ـ الربا والمعاملات المصرفية في نظر الثريعة ـ د. عمر بن عبد العزيز المترك ـ دار

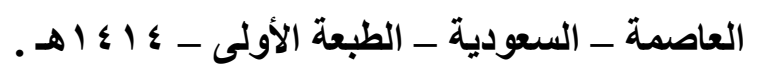

ـ رد المحتار على الدر المختـار المسمى حاثية ابن عابدينــ. دار إحياء التراث

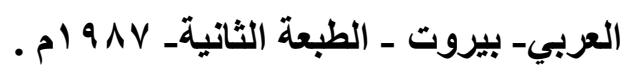
- روضـة الطـالبين يحيـى بـن شـرف الـدين النـووي ـ الطبعـة الثانيـة ـ ط. المكتب الإسلامي - بيروت . - المي 
ـ شـرح منتهى الإرادات ـ منـصور البهوتي ـ ط. عـالم الكتب - بيزوت ـ الطبعة

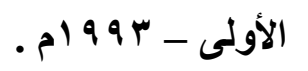

ـ الثنامل في المعاملات وعمليات المصارف الإسلامية ـ د.محمود عبد الكريم أحمد -

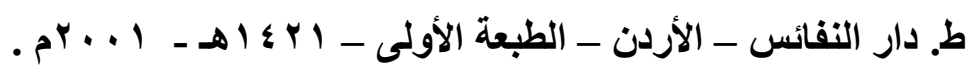

ـ شرح فتح القدير لكمال الدين محمد عبد الواحد السيواي المعروف بابن الههام ـ ط.

$$
\text { دار الفكر- بيروت ـ الطبعة الثانية . }
$$

$$
\text { ـ شرح منح الجليل - محمد عليش - ط. دار صادر - القاهرة . }
$$

ـ عمليـات البنـوك مـن الوجهـة القانونيـة ـ د. علـي جمـال الـدين عـوض - ط. دار

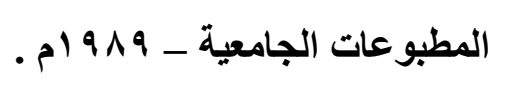

ـ غمز عيون البصائر ـ أحمد الحموي _ ط. دار الكتب العلمية ـ بيروت ـ الطبعة

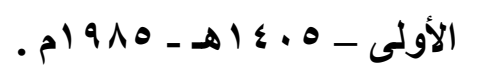

ـ القانون المدني الكويتي_ط. إدارة الفتوى والتشريع - الطبعة السادسة_ . . . r م .

ـ الفتاوى الهندية المسماة بالفتاوى العالمكرية ـ للثيخ نظام ـ ط. دار إحياء التراث

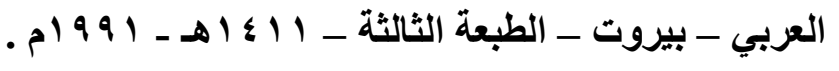

$$
\begin{aligned}
& \text { ـ الفروع لابن مفلح المقدسي - طباعة عالم الكتب - بيروت . }
\end{aligned}
$$

ـ قانون التجارة الكويتي-ط. إدارة الفتوى والتثريع - الطبعة الخامسة_ ... بrم .

ـ القاموس المحيطـ الفيروز آبادي ـ ط. مؤسسة الرسـالة_ بيروت ـ الطبعة الثانية ـ 
ـ القـاموس الفقهي لغة واصطلاحاً ـ د. سعيد أبو جيب ـ ط. دار الفكر - دمشثق -

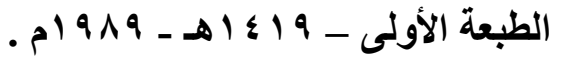

ـ القانون التجاري ـ د. علي البارودي - د. محمد فريد العريني ـ ط. دار المطبوعات

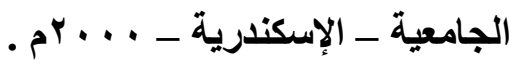

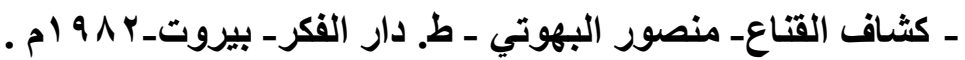

ــ المبسوط ـ لـشمس الـدين السرخسي ـ ط. دار الكتب العلميـة ـ بيـروت ـ الطبعـة

$$
\text { الأولى - ب } 999 \text { 1م - لامي - مصر . }
$$

ـ مجمع الضمانات ـ الكاساني ـ ط. دار إحياء الكتاب الإسلامي .

$$
\text { ـ المجموع - شرح المهذب للنووي - ط. دار الفكر - بيروت . }
$$

ـ مجموعة التشريعات الكويتية ــ الجزء السادس ـ الطبعة الرابعة ـ ب ج9 ام ـ إدارة

$$
\text { الفتوى والتشريع . }
$$

ـ مختصر أحكام المعاملات الشرعية ـ علي الخفيف ـ ط. مطبعة السنة المحمديـة ـ

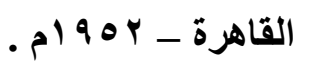

ـ المـصباح المنيـر الفيومي ـ ط. دار الكتب العلميـة ـ بيـروتــ الطبعة الأولى -

$$
\text { - المصنف - ابن أبي شيبة - ط. دار الفكر - بيروت . }
$$

ـ المعـاملات الشرعية الماليـة ـ أحمد إبـراهيم بـك ـ ط. مطبعة النصر - القـاهرة ـ

$$
\text { . }
$$


ـ المعاملات المالية المعاصرة ـ د. محمد عثمـان شبير - ط. دار النفائس - عمـان -

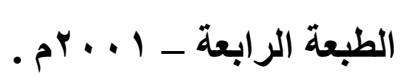

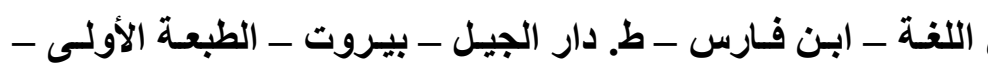

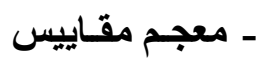

- 1991

ـ المعجم الوسيط ـ الطبعة الثانية ـ مطابع دار المعارف ـ مصر ـ

ـ معجم المصطلحات الاقتصادية في لغة الفقهاء ـ د. نزيـه حمـاد ـ ط. المعهد العـالمي

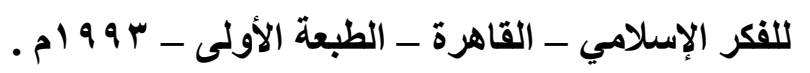

ـ المغرب في ترتيب المعرب ـ أبو الفتح ناصر المطرزي ـ ط. دار الكتاب العربي -

$$
\text { بيزوت }
$$

$$
\text { - مغني المحتاج- للخطيب الثربيني - ط. دار الفكر- بيروت . }
$$

ـ المغني لابن قدامة ـ ط. مكتبة الجمهورية العربية .

ـ المنتقى - سليمان الباجي - ط. دار الكتاب الإسلامي - القاهرة .

ـ المنفعـة في القرض ـ د. عبد الله بـن محمــ الهمرانـي ـ ط. دار ابـن الجـوزي -

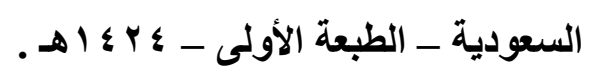

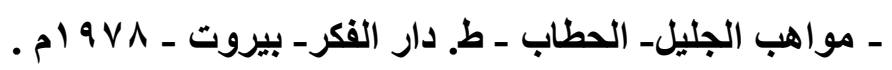

ـ موسوعة أعمال البنوك ـ د. محي الدين إسماعيل علم الدين - ط. دار النسر الذهبي

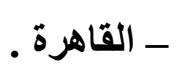

ـ الموسوعة الفقهية الكويتية - وزارة الأوقاف الكويتية .

ـ نهاية المحتاج شرح المنهاج - شمس الدين الرملي ـ ط. مصطقى البابي الحلبي -

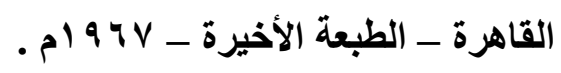

